IZA DP No. 8870

The Educational Upgrading of Japanese Youth, 1982-2007: Are All Japanese Youth Ready for Structural Reforms?

Yoichi Arai

Hidehiko Ichimura

Daiji Kawaguchi

February 2015 


\title{
The Educational Upgrading of Japanese Youth, 1982-2007: Are All Japanese Youth Ready for Structural Reforms?
}

\author{
Yoichi Arai \\ National Graduate Institute for Policy Studies (GRIPS) \\ Hidehiko Ichimura \\ University of Tokyo \\ Daiji Kawaguchi \\ Hitotsubashi University and IZA
}

Discussion Paper No. 8870

February 2015

IZA

P.O. Box 7240

53072 Bonn

Germany

Phone: +49-228-3894-0

Fax: +49-228-3894-180

E-mail: iza@iza.org

\begin{abstract}
Any opinions expressed here are those of the author(s) and not those of IZA. Research published in this series may include views on policy, but the institute itself takes no institutional policy positions. The IZA research network is committed to the IZA Guiding Principles of Research Integrity.

The Institute for the Study of Labor (IZA) in Bonn is a local and virtual international research center and a place of communication between science, politics and business. IZA is an independent nonprofit organization supported by Deutsche Post Foundation. The center is associated with the University of Bonn and offers a stimulating research environment through its international network, workshops and conferences, data service, project support, research visits and doctoral program. IZA engages in (i) original and internationally competitive research in all fields of labor economics, (ii) development of policy concepts, and (iii) dissemination of research results and concepts to the interested public.
\end{abstract}

IZA Discussion Papers often represent preliminary work and are circulated to encourage discussion. Citation of such a paper should account for its provisional character. A revised version may be available directly from the author. 
IZA Discussion Paper No. 8870

February 2015

\title{
ABSTRACT
}

\section{The Educational Upgrading of Japanese Youth, 1982-2007: Are All Japanese Youth Ready for Structural Reforms?*}

\begin{abstract}
Are all Japanese youth ready for the structural reforms proposed as a supply-side policy of Abenomics? To answer this question, we assess how well Japanese youth have coped with the labor market's long-term structural changes, induced primarily by deepening interdependence with emerging economies and rapid technological progress over the last three decades. We examine the role of educational upgrading on the labor-market outcomes of youth between the ages of 25 and 29, using six waves of micro data from the Employment Status Survey spanning from 1982 to 2007. The analysis demonstrates that the demand growth for skilled labor relative to unskilled labor has been met by the educational upgrading of youth through the expansion of tertiary education, including education in vocational schools. Youth left behind the trend of educational upgrading, however, have suffered significantly from decreasing employment opportunities and deteriorating working conditions.
\end{abstract}

JEL Classification: $\quad$ 123, J21

Keywords: tertiary education, youth employment, Japan

Corresponding author:

Daiji Kawaguchi

Graduate School of Economics

Hitotsubashi University

Naka 2-1, Kunitachi-shi

Tokyo, 186-8601

Japan

E-mail: kawaguch@econ.hit-u.ac.jp

\footnotetext{
* An earlier version of this paper was prepared for the conference on Abenomics hosted by Tokyo Center for Economic Research on March 7, 2014 at the University of Tokyo. We received valuable comments from the conference participants. We are especially grateful to Ayako Kondo, the formal discussant at the conference, for many helpful comments. We also gratefully acknowledge the comments from a referee that significantly improved the manuscript. This research was supported by Grants-in-Aid for Scientific Research No. 22243020, No. 23330070 and No. 23330079 from the Japan Society for the Promotion of Science.
} 


\section{Introduction}

Are all Japanese youth ready for the challenges posed by restructuring of industries, deepening international dependence of economic activities, and rapid technological progress? Answering this question provides a fundamental perspective on the success of so-called Abenomics led by Prime-minister Shinzo Abe. Since he took office in December 2012, a series of monetary and fiscal policies allegedly succeeded in resolving demand shortages, and the labor-supply constraint became apparent, as evidenced by the low unemployment rate and wage increase. As the final step of Abenomics, the government is expected to implement supply-side reforms, such as lowering tariffs in specific industries, deregulating product markets, and reforming the labor market. If the government manages to implement these reforms, labor demand, particularly that for skilled workers, is expected to expand. How can Japanese workers, youth in particular, respond to the labor demand growth? Does the rising tide lift all boats? If not, who are likely to be left behind?

Meanwhile, Prime Minister Abe emphasizes the importance of preparing youth for the rapid progress of the global interdependence of economic activities and providing women career opportunities to accommodate future labor shortages because of the rapidly aging population (New Growth Strategy: The Formulation of "Japan Revitalisation StrategyJapan is Back-," June 21, 2013). Hence we pay particular attention to the youth labor market and ask whether all Japanese youth are ready to adapt to the skill demand growth that will presumably follow the proposed reforms. To examine whether Japanese youth are ready to adapt to the new economic environment, we examine how well they have accommodated environmental changes over the past three decades and attempt to identify the obstacles, if any, that have impeded the adaptation.

The performance of the Japanese youth labor market over the past three decades has been less than stellar. Many studies point to a significant deterioration of youth labor-

market outcomes, particularly in terms of the employment rate (e.g. Genda (2006) and Mitani (2008)). We do not intend to challenge the view established in previous studies that 
youth labor-market conditions have worsened significantly over the last two decades in the period of long-term economic malaise. We instead attempt to explain the fact, which is less frequently pointed out, that the employment rate of Japanese male youth between the ages of 25 and 29 continues to be the highest among major developed countries and that the female youth employment rate has become one of the highest from being among the lowest over the last three decades.

In this paper, we demonstrate that educational upgrading, particularly the increase in the advancement rate to tertiary education, plays a significant role in maintaining a relatively high employment rate among Japanese youth. An analysis of the Employment Status Survey between 1982 and 2007 reveals that the employment rate of males between the ages of 25 and 29 dropped significantly among less-educated groups, but its drop was limited among moreeducated groups. In the same period, the fraction of junior/technical college or university graduates increased. Consequently, had there been no educational upgrading among male youth, their employment rate would have dropped by 7 percentage points instead of the 6 percentage points that we observed in reality. The role of educational upgrading was more significant among female youth. The employment rates of all educational groups increased between 1982 and 2007, but the growth was more significant among more educated groups. Concurrent educational upgrading of female youth accordingly contributed to an increase in their employment rate; had there been no educational upgrading, the increase of employment rate would have been limited to 17 percentage points instead of the actual 22 percentage points.

A decreasing youth population, as shown in the size of the 18-year-old population-about 2 million in 1990 and 1.2 million in 2010, may well have contributed to keeping youth employment relatively high compared with other developed countries, but population decline alone cannot explain the fact that the employment rate of educated youth declined less than that of youth with comparatively less education. We argue that educational upgrading of the Japanese youth, enabled by a combination of youth population decrease and expansion 
of capacity in higher educational institutions, accommodated the relative demand growth for skilled workers. Meanwhile, less-educated youth suffered from demand decline, as shown in the example that the employment rate of male junior-high school graduates dropped from 93\% in 1982 to $80 \%$ in 2007. Even among those who are employed, less educated youth are significantly more likely to work under unstable contracts, so-called non-regular contracts. While the fraction of non-regular employment has increased among all educational groups, the increase of non-regular employment is more pronounced among less educated youth. In addition, the educational upgrading of Japanese youth in the last three decades contributed to keeping the overall employment rate high, but those who were left behind the trend of educational upgrading suffered severely from the decrease in employment opportunities and the deterioration of working conditions. Given continuous educational upgrading, we expect that Japanese youth in general are ready for relative demand growth for skilled labor induced by structural reforms included in Abenomics, but we need to take measures to bottom up the skills of youth, for example, by enacting policies to reduce the number of high-school dropouts.

\section{Japanese youth's employment rate in the interna- tional context}

Japan's extremely low unemployment jumped after the two oil crises in 1974 and 1979 and decreased in the late 1980s when the economy boomed. It then increased steadily after the bubble burst in 1991, as illustrated in Figure 1. The source of the high and persistent unemployment rate has been the subject of intensive research. A number of attempts have been made to identify the causes this high and persistent unemployment.

These explanations include labor-market segmentation (Abe and Ohta, 2001), worker flows (Kuroda, 2003, Ling and Miyamoto, 2012), cyclical behavior (Miyamoto, 2010), and regional patterns of low-skilled labor (Abe and Tamada, 2010). Among the various plausible 
causes, Genda (2007)'s influential book points out that lack of demand after the burst of the economic bubble in 1991 and the financial crisis in 1997 significantly shrank the port of entry to permanent jobs. The book first explains that youth in particular suffered from the rapid shrinkage of new job openings in response to adverse economic conditions; firms depend heavily on the adjustment of new recruits, because firing middle-aged workers is costly in terms of potential legal litigation and loss of reputation. The youth unemployment rate indeed has increased significantly over the last few decades. Figure 2 shows the unemployment rate for young workers (25-29 years old). The level depicted in Figure 2 in comparison to that in Figure 1 shows the seriousness of the youth labor market. The youth unemployment rate increased quite rapidly, because youth labor demand is sensitive to macroeconomic conditions. There is a broad consensus among labor economists that the Japanese youth labor market deteriorated during the long-term economic malaise. Kambayashi and Kato (2013), who generally challenge the popular belief that the employment quality languished during the long-term stagnation, empirically confirm the view that youth labor-market conditions indeed deteriorated, claiming, "[F] or one particular group of Japanese workers-youth, we find compelling evidence in support of the popular narrative."

While the situation looks bleak in the inter-temporal comparison, an international comparison provides a different perspective. Figure 3 shows the youth unemployment rate for 7 Organisation for Economic Co-operation and Development (OECD) countries. Japan's youth unemployment rate was exceptionally low until the mid-1990s. Despite the steady increase from the 1990s until the early 2000s, Japan's extent of youth unemployment can still be considered as the lowest among the 7 countries, partly because of the Japanese unemployment rate's insensitivity to the financial shock in 2008.

International comparisons among the OECD countries from the 1960s to the 1990s were conducted by Nickell, Nunziata, and Ochel (2005). They point out that much of the variation (about 55\%) among the OECD countries can be explained by changes in labor-market institutions, and the remainder was due to the deep recession. Remember that Japan ex- 
perienced the great recession in the 1990s and the 2000s. If the recession can explain the remaining $45 \%$, it would be no surprise if we have observed much higher unemployment than what we have actually observed. Thus one of the main objectives of this paper is to investigate factors that contributed to maintaining the low unemployment rate despite the great recession.

To understand what causes the unemployment-rate movement, we pay attention to nonemployment rather than unemployment itself, because the inflow and outflow from unemployed to not-in-the-labor-force can play an important role in explaining unemployment movements, as discussed by Kuroda (2003). Figure 4 shows the employment-to-population ratio for young men for the same OECD countries as those in Figure 3. The movement of Japan's employment-to-population ratio is closely related to that of the unemployment rate. We observe a very high employment-to-population ratio until the mid-1990s. It then steadily declined from $93 \%$ to around 87\% until 2002 and stayed there until 2007, when it dropped to $85 \%$.

Figure 5 shows the employment-to-population ratio for young women for the same OECD countries.

Figure 5 exhibits a totally different trend. We observe an almost monotonic increase in Japan's employment-to-population ratio for the entire period, starting from around 50\% and climbing to over $70 \%$. Figures 4 and 5 show that it is important to study non-employment for men and women separately, and we proceed accordingly.

Next, we provide an overview of the educational attainment of the young population (2529 years old) for seven countries considered in Figures 4 and 5. Figures 6 and 7 show the proportion of the population (25-29 years old) who completed tertiary education for men and women, respectively, based on the data from Barro and Lee (2013). Tertiary education, defined by the UNESCO International Standard Classification of Education (ISCED), includes junior colleges, colleges, and universities.

In general, junior colleges include two-year vocational schools, which correspond to a 
specialized course of specialized training college (Senshugakko senmon katei) in the case of Japan. ${ }^{1}$ Among males, the proportion of the young population who have completed tertiary education is high in Japan and the United States relative to the other five countries, as indicated in Figure 6, corresponding to the high employment rates in these two countries, as reported in Figure 4. The relationship between high educational attainment and high employment rate is less clear for the United Kingdom, however. It is also interesting to note that the decline in the proportion of educational attainment for France, Spain, and Italy mirror those of the respective employment rates. Although the evidence is not definitive, the two figures suggest a positive correlation between educational attainment and employment rates among youth.

The relationship between educational attainment and the employment rate is more pronounced for females than for males. Figure 7 shows the proportion of females among the youth population who completed tertiary education between the ages of 25 and 29 . As observed for the proportion for males, a significant part of the movements of educational attainment is paralleled by movements of the employment rate among females. It is striking that the proportion of Japanese females who completed tertiary education increased monotonically from below $10 \%$ in the 1980 s to above $50 \%$ in 2010 , and, during the same period, the employment rate increased monotonically from $50 \%$ to $70 \%$. Since the relationship between educational attainment and the employment rate is only suggested by international comparison, in the following, we will take a closer look at the role of educational attainment for employment in Japan.

Before proceeding to the detailed analysis based on Japanese data, we examine a plausible hypothesis that the decreasing size of the youth population in Japan explains the high employment-to-population ratio. The size of the population between the ages of 25 and 29 decreased from about 10 million around 2000 to about 7.2 million in 2012. This rapid

\footnotetext{
${ }^{1}$ Typically, tertiary education includes programs at the ISCED level 5 and above. The ISCED mapping for each country can be found at the UNESCO Institute for Statistics. http://www. uis.unesco.org/Education/ISCEDMappings/Pages/def ault. aspx.
} 
youth population shrinkage may have helped youth find jobs and keep their employment-topopulation ratio high, because a larger cohort size generally crowds youth out of the labor market (Korenman and Neumark (2000)). To assess this possibility, Figures 8 and 9 draw the youth compositions as percentages of all ages. Figures indicate that the composition of youth aged 25-29 in Japan indeed sharply plummeted after 2001.

Two facts, however, indicate that there exists an important mechanism to be explained over the hypothesis that population shrinkage explains the high employment-to population ratio in Japan. First, the composition of youth had rapidly increased from 1993 to 2000 when the employment-to-population ratio had remained high among males and had increased among females. Second, Japan is not alone in experiencing a youth population shrinkage. The relative population trajectories of Italy after 2000 are close to those of Japan, but the fractions of youth with tertiary degrees did not increase, unlike Japan (Figures 6 and 7) and their employment population ratios are kept low (Figures 4 and 5). The experience of Italy suggests that shrinkage of the youth population alone (i.e., not accompanied by their

educational upgrading) may not necessarily contribute to a high employment-to-population ratio.

\section{Data}

We use the Employment Status Survey (ESS), which is a household survey conducted every five years based on a two-step stratified sampling method; the first step randomly selects about 32,000 census tracks from 8 strata, and the second step randomly samples 440,000 dwelling units. The survey asks respondents to report the employment status and the educational background, along with demographic information, of each household member aged 15 or older. We construct the analysis sample by extracting the sex, age, educational background, and employment status of each household member from the micro data for the years 1982 through 2007. We restrict our analysis sample to those between the ages between 25 and 29 with valid demographic variables and education/employment status. The sample size 
of each year ranges from 53,000 in 2007 to 78,000 in 1997, which reflects the small population of the cohort born around 1980 and the large population of the cohort born around $1970 .^{2}$

The ESS records each household member's educational background in one of four categories until 2002: 1: junior high school (9 years of education); 2: high school (12 years of education); 3: junior college, technical college, and vocational school (13-15 years of education); and 4: university or more (16+ years of education).

The first category includes junior high school. Completing 3 years of junior high school, after completing 6 years of primary school, has been compulsory since 1947. Therefore, every individual in our analysis sample completed junior high school. Of those who have only a junior-high-school education, about one half are likely to be high-school drop outs. ${ }^{3}$

The second category, high schools, typically admits junior-high-school graduates based on their academic performance on the entrance examination and requires three years to complete. The curriculum is either general or vocational, and the majority of students attend general high schools. ${ }^{4}$

The next two categories are classified into tertiary education based on the UNESCO standard. The third category, junior college, technical college, and vocational school, nests a variety of educational institutions. Junior colleges typically admit high-school graduates to a 2-year curriculum on liberal arts, which is traditionally designed for women. The number of students attending junior colleges has been declining, and the number of women attending 4-year colleges/universities is increasing. Technical colleges admit junior-high-school graduates to a 5-year curriculum, which typically focuses on engineering subjects. Technical colleges expanded rapidly during the 1960s to accommodate the growing demand for engi-

\footnotetext{
${ }^{2}$ The large cohort population born around 1970 consists of the children of the baby boom generation.

${ }^{3}$ According to the Basic Survey of Schools by Ministry of Education, Culture, Sports, Science and Technology, as of 2011, 98 percent of junior-high-school graduates proceed to high school, but about 2 percent of them drop out from high school.

${ }^{4}$ According to the Basic Survey of Schools conducted by the Ministry of Education, Culture, Sports, Science and Technology, as of 2010, 72 percent of high-school students attend the general course, 8 percent attend a manufacturing course, 7 percent attend a commercial course, 5 percent attend a comprehensive course that offers a mixture of general and vocational courses, and 3 percent attend an agricultural course. The remaining minority attend such courses as homemaking, social work, nursery, fishery, informatics, and miscellaneous courses.
} 
neers because of rapid industrialization. Vocational schools are nontraditional educational institutions that admit high-school graduates with a few exceptions, offering 1 to 3 years of a curriculum on practical subjects, such as nursing, architecture, and computer engineering, among others.

The fourth category includes universities and graduate schools. Universities admit highschool graduates and offer a 4 -year curriculum. ${ }^{5}$ Each school is divided by academic discipline, such as law, economics, literature, natural science, engineering, and medical departments. Each department admits students based on their performance on the entrance examination. Graduate schools admit 4-year university graduates and consist of a 2-year master's course and a subsequent 3-year doctoral course.

The Ministry of Education of the Japanese government regulates the curriculum up to high school; primary, junior high, and high schools must choose textbooks from among the books approved by the Ministry. While the Ministry does not regulate the university curriculum in detail, founding a university or expanding student capacity must be approved by the Ministry. The screening process had been strict until the criteria were loosened in 1992. Vocational schools are a unique exception from the strict governmental regulations, as represented by the fact that Article 1 of the School Education Act does not define vocational schools as being among the schools treated by the Act. Meanwhile, Article 130 of the Act requires that the founding of a school must be approval by the prefectural governor; the establishment or capacity expansion need not be approved by the central government, as in the case of the other tertiary educational institutions.

The 2007 survey significantly expands the questionnaire on educational background. The third category used until 2002 is divided into two distinct categories: junior and technical college and vocational school. The fourth category used until 2002 is divided into two: university and graduate school. We will later closely examine this specific survey year to shed light on the function of tertiary educational institutions in detail.

\footnotetext{
${ }^{5}$ There is a 6-year curriculum for medicine, dentistry, veterinary medicine, and pharmacy.
} 


\section{Educational upgrading and the employment rate of Japanese youth}

This section demonstrates that upgrading the educational background of Japanese youth contributed to keeping their employment rate high relative to a counterfactual scenario under the absence of the educational upgrading; the educational upgrading of male youth mitigated the employment-rate decline and that of female youth promoted the employmentrate increase.

\subsection{Male employment rates by educational background}

To assess the role of educational upgrading in mitigating the deterioration of the employment rate of young adult males, we first take a close look at the changes of the employment rate of males between the ages of 25 and 29 by educational background, and they are presented in Figure 10. The figure shows that the employment rates of all education groups fell over the last two-and-a-half decades. The deterioration was most pronounced among junior-highschool graduates: The employment rate dropped significantly, from $93 \%$ in 1982 to $80 \%$ in 2007. Figure 11 shows the educational composition for young adult males from 1982 to 2007. The drop was least significant among university graduates, whose employment rate was $98 \%$ in 1982 and $94 \%$ in 2007. The more significant drop of the employment rate among lesseducated youth is striking, given the fact that the fraction of the less educated among the whole youth population has significantly declined, as reported in Figure 11, and this reflects the demand shrinkage for them, so that their offered wages went under their reservation wages. While one may argue that the increase of the reservation wage explains the fall of the employment rate among the less educated, Genda (2007) reports that the income effect, which is a major source of the increasing reservation wage, attenuated throughout the 1990s. Moreover, Abe and Tamada (2010) report that the extensive margin of wage elasticity among junior-high-school-graduate males is about 0.15 , which is reasonably high. 
While the employment rate of less-educated young males decreased between 1982 and 2007, the educational background of youth between 25 and 29 was upgraded. Figure 11 shows that the fraction of junior-high-school graduates decreased from $14 \%$ to $7 \%$ between 1982 and 1987 and stayed around 7\% after that time. The fraction of high-school-graduates hovered around 47\% between 1982 and 1992 and significantly dropped to $35 \%$ in 2007 . The sharp increase of junior/tech college or vocational school graduates largely compensated for the decline of high-school graduates. The fraction of this category increased monotonically from $6 \%$ in 1982 to $18 \%$ in 2007 . The fraction of university graduates stayed around $35 \%$ until 2002 and surged up to $41 \%$ in 2007.

The stagnated fraction of college graduates may need some explanation. As explained in the previous section, the founding as well as the expanding capacity of universities were heavily regulated until 1992, while the population size of 18 year olds peaked in 1990, because of the second set of baby boomers. The combination of limited capacity and growing cohort size depressed the fraction of college graduates among youth between the ages of 25 and 29 until early 2002. The deregulation and shrinking cohort size loosened the capacity constraint, resulting in a soaring fraction of college graduates between 2002 and 2007 (see Kawaguchi and Mori (2014) for details).

To summarize the findings for male youth, the fraction of high-school graduates dropped significantly and that of junior/tech college or vocational school graduates soared almost by the same amount as found in Figure 11. This educational upgrading, however, is expected to have a minor impact on the overall employment rate, because the difference between the employment rate of high-school graduates and that of junior/tech college or vocational school graduates is not very large, as indicated in Figure 10. We will formally demonstrate this after describing the trends for female youth. 


\subsection{Female employment rates by educational background}

Figure 12 draws the employment rates of female youth by their educational background. The overall employment rate of females between the ages of 25 and 29 increased from $50 \%$ in 1982 to $75 \%$ in 2007. Except for junior-high-school graduates, the employment rate of each group increased by about 20 percentage points during the same period. Since the level of the employment rate differs significantly across education groups, educational upgrading is expected to play a significant role for the overall increase in the employment rate. The employment rate of university graduates, for example, is at least 10 percentage points higher than that of high-school graduates in any arbitrary year between 1982 and 2007. Also, the employment rate of junior/tech college or vocational school graduates is at least 5 percentage points higher.

Figure 13 draws the composition of female youth's educational backgrounds. The fraction of junior-high-school graduates dropped from 12\% in 1982 to $5 \%$ in 1987 and hovered around $5 \%$ after that time. The fraction of high-school graduates decreased drastically from $57 \%$ in 1982 to $30 \%$ in 2007. This significant drop is compensated by an increase of junior/technical college or vocational school graduates, from $20 \%$ in 1982 to $38 \%$ in 2007 . The fraction of university graduates also increased, from $10 \%$ in 1982 to $28 \%$ in 2007 . The steady increase of female university graduates since 1992 makes a sharp contrast to the trends for males. To summarize the findings for females, the significant educational upgrading evidenced by Figure 13 would have contributed to the increase of their employment rate, because the employment rate is significantly higher for more educated than less educated youth. Again, this conjecture is assessed formally in the next subsection.

\subsection{Counterfactual simulation without educational upgrading}

We now quantify the contribution of educational upgrading on the overall employment rate. To attain this goal, we calculate the counterfactual employment rate if the educational composition had stayed at the 1982 composition. The counterfactual employment rate is 
calculated as:

$$
e m p_{t}^{1982}=\bar{x}_{1982} \hat{\beta}_{t}
$$

where $x$ is the vector of education dummy variables, and $\bar{x}_{1982}$ is the mean vector of the education dummy variables in 1982 . The estimated parameter $\hat{\beta}_{t}$ is obtained by regressing emp in year t on $x$ in year t. This counterfactual employment rate is compared to the actual employment rate, denoted as

$$
e \hat{m} p_{t}^{t}=\bar{x}_{t} \hat{\beta}_{t}
$$

Figure 14 displays the results of this exercise for males and females. For males, without the educational upgrading, the employment rate would have decreased by 7 percentage points, whereas the actual drop was 6 percentage points. The contribution of educational upgrading on the male youth employment rate may seem quantitatively limited, but the educational upgrading slowed the employment rate decline by about $15 \%$. In contrast, without educational upgrading, female employment would have increased by only 17 percentage points compared with the actual 22 percentage points. The difference between the actual growth and counterfactual growth is about one quarter of the actual growth. Therefore, the educational upgrading of females plays a quantitatively significant role in increasing the employment rate of young females. Without educational upgrading, the Japanese young female employment rate would have ranked in the middle of the OECD countries.

Our counterfactual analysis is likely to estimate the lower bound of educational upgrading on the employment rate, because we assume the independence of education-specific employment rates from the composition of educational backgrounds. In reality, as more high-school graduates proceed to tertiary educational institutions, the average ability of graduates from tertiary educational institutions falls, while the average ability of high-school graduates also falls. As far as we assume a single-peaked, symmetric distribution of ability and only students with ability above a threshold proceed to tertiary education, the effect of the decrease in the threshold on the mean ability is larger for graduates from tertiary educational institu- 
tions than for high-school graduates when less than half of high-school graduates proceed to tertiary educational institutions, as was the case in 1982. Accordingly, had the composition of educational background been constant as in 1982, we would have observed a greater divergence of employment rates by educational backgrounds because of the skill-biased demand shift. This is the primary reason why we speculate that our counterfactual simulation results are attenuated.

\subsection{Discussions on alternative explanations}

We should note that the youth population shrinkage after 2002 alone cannot effectively explain the reasons why the employment-to-population ratio remained relatively high among male youth and increased among female youth. Remember that the relative cohort size of youth aged 25-29 peaked around 2000. Were the population shrinkage the explanation, we should observe an increase of the employment-to-population ratio independent from educational upgrading. Therefore, the contribution of educational upgrading on the employmentto-population ratio, which is represented by the gap between actual and counterfactual lines in Figure 14, should have decreased after 2000. The apparent increase of the contribution of education to the employment-to-population ratio, represented by the widening gap of two lines in Figure 14 after 2000, indicate that the hypothesis cannot be the strongest mechanism at work. In addition, in the context of our discussion, it is entirely plausible that the youth population shrinkage enabled a higher fraction of a cohort to access tertiary education opportunities, because the capacity of the tertiary education is inelastic in the short run (Bound and Turner (2007) and Kawaguchi and Mori (2014)) and, through this channel, it has contributed to keeping the youth employment-to-population ratio high in Japan.

One could reasonably argue that the diminished preference for marriage among youth drives up both female educational attainment and their education-specific employment rates. Indeed, Abe (2011b) argues that the increase of young females' employment rate coincides with their decline of the marriage rate. Suppose that preference for marriage among fe- 
males declines and more females consider market production as being more important than household production. The increase of female labor-market attachment naturally increases the demand for education among them. In this scenario, the causality runs from employment to education. If the capacity of higher education does not expand to accommodate more females, however, the educational upgrading of females would be impossible. The limited educational upgrading of females arguably should have hindered their employment opportunities, given the demand growth for skilled workers relative to unskilled workers.

\subsection{Non-regular employment arrangements}

The increase of employees in flexible contract arrangements needs particular attention when discussing the youth labor market over the last three decades. Non-regular employees $(H i$ seishain) are the employees who tend to work shorter hours under fixed-term contracts without career perspectives. Previous studies, such as Asano, Ito, and Kawaguchi (2013), report that the increase in non-regular employees is concentrated among youth belonging to recent birth cohorts, reflecting the secular decline in long-term employment practices. Unstable employment of non-regular employees implies that their life-time income is lower than that of regular workers, conditional on current employment and current earnings. Indeed, Abe (2011a) reports that the transition from regular employment to non-regular employment reduces consumption by $12 \%$, conditional on changes in current earnings. We should cautiously note that the deterioration of youth employment stability occurs behind their relatively high employment rate.

We observe an increase of the fraction of non-standard workers in our ESS analysis data. The fraction of non-regular workers, defined based on their human resource management classification at the job (Kosho), among all workers has increased steadily over the last three decades, as shown in Figure 15. The fraction of non-regular workers among male youth increased from $4 \%$ in 1982 to $18 \%$ in 2007, whereas among female youth it increased from $18 \%$ in 1982 to $38 \%$ in 2007. 
We further examine which educational groups had more pronounced increases of nonstandard employment by regressing a non-standard dummy variable on year and age dummy variables using working youth aged between 25 and 29 as the analysis sample. Table 1 tabulates the estimated coefficients of the linear probability model. Among male workers, the coefficients for year dummy variables show that the fractions of non-regular workers increased significantly after 1997. While we observe significant increases of non-regular employees in all education groups, the increase is more pronounced among less educated workers. The fraction of non-regular employment increased by 18 to 19 percentage points between 1982 and 2007 among non-university graduates, whereas the increase was 10 percentage points among university graduates. The increase of non-regular employment among females is more significant, and the increase is more pronounced among less educated workers. Between 1982 and 2007, the fraction of non-regular workers increased by 43 percentage points among junior-high-school graduates, whereas it increased by 10 percentage points among university graduates.

We have already observed that the male employment rate of less educated workers dropped significantly between 1982 and 2007. The analysis of non-regular employment further reveals that the employment stability of the less-educated has deteriorated significantly even among those who work. The female employment rate increased significantly between 1982 and 2007, but the increase was realized mainly through an increase of non-regular employment among the less-educated. Overall, less-educated youth of both sexes suffered more from the increased job instability over the last three decades than their more educated counterparts.

The analysis of non-regular employees complements our existing results; less skilled male workers experienced a deterioration in the quality of employment in addition to fewer employment opportunities. The increased employment rate among females comes in form of non-regular employment disproportionately among less educated females. These findings are consistent with a hypothesis that the demand shift in favor of educated workers is more 
pronounced if we focus on regular employment.

\subsection{Changes in occupational composition}

We document a significant educational upgrading of Japanese youth for both sexes, but their educational upgrading may well be a result of a supply increase of tertiary-educated workers without a demand increase for them. To address this concern, we first examine if the fraction of workers engaging in high-skill occupations had increased between 1982 and 2007. Figure 16 tracks the fraction of male workers engaging in each of nine occupations that can be consistently constructed throughout the 1982-2007 period: professional, administra-

tive, clerical, sales, agricultural, production, transportation and communication, security, and service occupations. Somewhat surprisingly, the fraction of production workers, typically less-educated workers, did not decrease significantly during the analysis period, but we cannot rule out the possibility that production workers shifted from workers in assembly lines to lower-level engineers. The lack of a consistent detailed occupational code, however, prevent us from confirming this conjecture. The fractions of workers in sales, clerical, and transportation and communication occupations decreased, while the fractions in professional and service occupations increased.

The fraction of female workers in clerical occupations decreased significantly after 1997. We conjecture that this trend is largely due to the penetration of information and communication technologies into workplaces. The fraction of female production workers secularly decreased throughout the sample period, while the fraction of professional, sales, and service occupations increased significantly.

Figure 17 plots the changes of the fraction in each occupation against the hourly wage rate in 1982 to articulate the relationship between the skill content of each occupation and its growth. The scatter diagrams show nothing definitive but suggest that occupation growth was more concentrated among high-paying jobs in 1982. In particular, the growth of professional occupations among both sexes is quite notable. Overall, the results of the 
occupational analysis at least do not contradict the demand growth for skilled workers, but the rough occupational categories that are consistent between 1982 and 2007 prevent us from deriving a definitive conclusion.

To overcome the limitation of the occupational analysis, an examination of wage differentials by educational background is warranted to examine whether the quantity increase of tertiary-educated workers matched the demand increase for them. If the speed of the supply increase of tertiary-educated workers surpassed the speed of the demand increase for them, the return to tertiary education should have decreased.

We rely on the Basic Survey of Wage Structure (BSWS) by the Ministry of Health, Welfare and Labor to examine the time series of real hourly wage by educational background. The BSWS is an annual survey of establishments randomly selected from establishments that hire more than 5 employees. The annual survey includes about 1.5 to 1.7 million workers from 70,000 to 80,000 establishments. Hourly wage for each worker is calculated as scheduled monthly wage plus one-twelfth of annual bonus in the last year, divided by scheduled monthly hours worked plus monthly overtime hours. Hourly wage is deflated by the Consumer Price Index to the 2010 price. A caveat is that the BSWS asks for the educational background of full-time workers only and does not ask for that of part-time workers. Therefore, we are forced to limit our analysis to full-time workers.

Figure 18 illustrates the mean log real hourly wage by the educational background of males between the ages of 25 and 29. Real wages increased rapidly between 1987 and 1993, reflecting the macroeconomic boom. Then real wages were on declining trends for all education groups until 2012, except for university graduates, whose wage decline has been stopped since 2000. These wage declines or stagnations reflect the macroeconomic stagnation of Japan during the period. Reflecting the differential wage trends between university graduates and high-school graduates, the wage differential between university and high-school graduates has increased since 2000. The wage differential between junior/technical college graduates and high-school graduates has been stable, between 0 and 0.05 log points. It is notable 
that the return to tertiary education at least did not decrease, regardless of the significant increase of tertiary-educated workers. The increase of the return to university education and the stable return to junior/technical college education refute the claim that the supply of tertiary-educated workers increased without the existence of demand growth for them.

Figure 19, which illustrates the mean log wage of females between the ages of 25 and 29, indicates that the mean log real wage increased until 1993 for all education groups. The wage was almost stagnant after that year, while the wage decline was not so severe as that for male workers. The wage differential between university graduates and high-school graduates was around 0.25-0.30 log points between 1990 and 2010. The wage differential between junior/technical college graduates and high-school graduates was around 0.15 log points between 1990 and 2010. Similar to the trends for males, the return to tertiary education has been stable over the last two decades, while the quantity of tertiary-educated workers significantly increased during the same period. A significant increase of tertiary-educated workers with a stable return to tertiary education implies that both demand for and supply of tertiary-educated workers have increased over the last two decades.

As a digression, it is worth mentioning the gender difference in returns to education. A comparison of Figures 18 and 19 reveals that the return to higher education is higher for female workers than for male workers. There are arguably two major reasons for this. First, as shown in the next section, there are significantly more male workers than female workers in the construction and manufacturing sector. Many less-educated male workers work in the construction and manufacturing sector as blue-collar workers and earn higher wages, so that higher wage compensates for worse working environments, as the compensating wage differential theory predicts. Better employment opportunities for less-educated male workers tend to suppress the return to education. Second, among tertiary-educated workers, male workers are more likely to be involved in long-term implicit employment contracts and face steeper experience-wage profiles than female workers (Miyoshi (2008)). As a result, the return to education evaluated between the ages of 25 and 29 tends to be smaller among male 
workers than among female workers.

The argument in this section has demonstrated that the evolution of the occupational structure and the wage differentials by educational background corroborate with the skillbiased labor-demand shift without explicitly mentioning the determinants behind the shift. While identifying the determinants for the skill-biased labor-demand shift is beyond the scope of the current paper, the received wisdom in the literature enables us to point to two possible factors, technological progress and globalization, as major determinants.

The first potentially important factor is technological progress. Effects of technological change, especially skill-biased technological changes (SBTC), on wages and demands for skilled and unskilled workers are studied theoretically and empirically by Bound and Johnson (1992), Berman, Bound, and Griliches (1994), Johnson (1997), Berman, Bound, and Machin (1998) and Machin and Van Reenen (1998), among others. These studies find an increase in the relative demand for skilled workers and a rise in their relative wages. Machin and Van Reenen (1998) finds a clear effect of SBTC for seven OECD countries, including Japan. Sakurai (2001) investigates the influence of SBTC for manufacturing in Japan and reaches the same conclusion. Although they found strong evidence in manufacturing, the effect is also profound in service sectors, as discussed in Levy and Murnane (1996).

Second, increased dependence of national economies also could have been important for the low-skilled labor force. Increased openness affects wages and demands for skilled and unskilled workers in several ways. Two major paths considered in the literature are through international trade and foreign outsourcing. First, an increase in international trade can cause reallocations in employment via Stolper-Samuleson effects. Sachs and Shatz (1994) and Krueger (1997) recognize the influence of international trade on wages for skilled workers. Borjas and Ramey (1995) point out that international competition is a major cause of demand shifts for skilled workers. The contribution of increased trade to employment, however, is found to be small relative to SBTC, at least in the US, by Berman, Bound, and Griliches (1994), Johnson (1997) and Berman, Bound, and Machin (1998). Sakurai (2004) 
finds that the effect of international trade is not large for the Japanese labor market. Second, foreign outsourcing can affect the labor market, because importing unskilled-intensive (intermediate) goods leads to a shift of employment to skilled workers within industries. Feenstra and Hanson $(1996,1999)$ find substantial increases in wages and demand for skilled workers in the U.S. labor market. For Japan, Ahn, Fukao, and Ito (2008) observe an increase in the relative demand for skilled workers due to outsourcing to Asia.

\section{Restructuring of industrial composition}

We have argued that the increase of tertiary-educated Japanese youth over the last twoand-a-half decades has been met by a demand increase for these workers. How were the increased number of educated workers absorbed into different industries, whose composition was itself changing? The upper panel of Table 2 tabulates the industrial composition of male workers aged 25-29 for each year. The fraction of workers in construction and manufacturing is rather stable. Around $13 \%$ of males aged 25-29 work in the construction industry and $25 \%$ work in the manufacturing industry. Major compositional changes were a decrease in retail and wholesale industries and an increase in the service industry. More striking are changes in the fractions of tertiary-educated workers in each industry reported in the lower panel of Table 2. In the previous section, we confirmed that the return to tertiary education did not decrease during the analysis period. If young workers are mobile across industries and consequently the returns to education in each industry are identical, the increase of tertiary-educated workers in each industry implies that the demand for tertiary-educated workers in each industry increased.

The overall increase of tertiary-educated workers can be attributed to the increase in the employment share in the industry that originally hired more tertiary educated workers and the increase of tertiary-educated workers within each industry. We call the former effect the between (industry) effect and the latter the within (industry) effect. More specifically, the

fraction of tertiary-educated workers in year $t$, denoted by $p_{t}$ is decomposed as $p_{t}=\sum_{i} p_{i, t} x_{i, t}$ 
where $p_{i, t}$ is the fraction of tertiary-educated workers in industry $i$ in year $t$ and $x_{i, t}$ is the employment fraction of industry $i$ in year $t$. We first use the 9 industries listed in Tables 2 and 3. Using this relationship, the change in the fraction of tertiary-educated workers is decomposed as:

$$
p_{2007}-p_{1982}=\sum_{i}\left(p_{i, 2007,}-p_{i, 1982}\right) x_{i, 1982}+\sum_{i} p_{i, 2007}\left(x_{i, 2007}-x_{i, 1982}\right)
$$

This is a Oaxaca-Blinder decomposition. The first term corresponds to the within effect, and the second term corresponds to the between effect. Of the 23-percentage-point increase of tertiary-educated workers, 22 percentage points are attributed to the within effect and the other 1 percentage point is attributed to the between effect. The results imply that the demand growth for tertiary-educated workers in each industry combined with the supply increase of these workers in each industry is the main driver for skill upgrading between 1982 and 2007.

The upper panel of Table 3 tabulates the industrial composition of female youth employment, and the lower panel of the same table tabulates the fraction of tertiary-educated workers in each industry. Contrary to the finding for male workers, the decrease in the fraction engaged in manufacturing, from $20 \%$ in 1982 to $13 \%$ in 2007, is apparent. Along with the findings for male workers, the fraction engaged in the retail and whole sale industry decreased, and those in service industry increased. The lower panel reveals that the fraction of tertiary-educated workers increased in all industries. The decomposition analysis reveals that of the 35-percentage-point increase of tertiary-educated workers, 32 percentage points are attributed to the within effect, and the other 3 percentage points are attributed to the between effect.

One may be concerned that we obtained a small industrial composition effect because the industry classification consists of only 9 industrial codes. To address this reasonable concern, we constructed a more detailed set of industry codes based on two-digit industry 
codes that include 38 industries. ${ }^{6}$ The Oaxaca-Blinder decomposition applied to men reveals that of the 22-percentage-point increase of the fraction of tertiary-educated workers, only 2 percentage points are explained by the compositional change of industries, and the other 20 percentage points are attributed to within-industry skill upgrading. For women, of the 35-percentage-point increase of the fraction of tertiary-educated workers, about 4 percentage points are explained by the compositional change, and the other 31 percentage points are explained by the increase of female tertiary-educated workers across industries. In sum, using the detailed industry code does not change our findings.

The industrial analysis reveals that the demand for tertiary-educated workers has increased universally across industries and that the increased supply of tertiary-educated workers is absorbed into various industries. Even in industries that were dominated by low-skilled workers in 1982, the skill demand has increased over the past two-and-a-half decades. The contemporaneous increase of tertiary-educated workers has matched the demand increase. SBTC is the most probable cause of the demand shift for skilled workers within an industry. The dominant role of a within-industry demand shift rather than a between-industry demand shift is consistent with findings in many previous studies, such as Katz and Murphy (1992).

\section{The roles of vocational school and graduate school}

The analysis based on the ESS and the BSWS reveals that the Japanese economy has experienced a demand increase for skilled workers, sharing the experience with many other developed countries, and the supply increase of tertiary-educated workers coincided with the demand increase. With this big picture in the background, we are interested in more

\footnotetext{
${ }^{6}$ This classification is the finest possible classification that allows us to construct a consistent industry code that covers 6 surveys between 1982 and 2007. The industries include Agriculture, Forestry, Fishery, Mining, Construction, Food, Textile, Wooden products, Paper products, Publishing, Chemical, Ceramics, Steel, Metal, Metal product, Machinery, Electric machinery, Transport machinery, Precision machinery, Other manufacturing, Public utilities, Communication, Wholesale, Railway, Logistics, Food retail, Non-food retail, Finance, Real estate, Restaurant, Health, Education/academic, Professional service, B to C service, Maintenance, B to B service, Other services, and Public sector.
} 
detailed categories within tertiary education. Tertiary education includes junior college, technical college, and vocational school (13-15 years of education) and university or more (16+ years of education). While government statistics consistently allow us to distinguish those with 13-15 years of education from those with 16 or more years of education over the last two-and-a-half decades, the ESS started to make finer distinctions within each education category in 2007.

From 2007, ESS gave respondents the following choices for describing their educational background: 1. primary school or junior high school, 2. high school, 3. vocational school, 4. junior/technical college, 5. university, and 6. graduate school. Table 4 tabulates the distribution of the detailed categories of the educational background of Japanese youth in 2007. Among the people who were classified as graduates of vocational school or junior/technical college before 2007, $83 \%(=15 / 18)$ of males and $51 \%(=20 / 39)$ of females were indeed vocational-school graduates. The analysis of vocational-school education on labor-market outcomes is limited to a few studies based on smaller samples, such as Nagao (2008) and Hamanaka (2009), but this high fraction of vocational-school graduates warrants more studies on the role of vocational-school education in the labor market.

It is also worth noting that the fraction of workers with graduate degrees is not negligible, particularly among males. As many as $14 \%(=6 / 42)$ of male workers who were formerly classified as university graduates have graduate degrees and $6 \%(=2 / 32)$ of females have graduate degrees. As already pointed out by Morikawa (2012), a detailed study on the function of graduate education in the labor market is needed.

As a first cut of the analysis to estimate the effect of education on labor-market outcomes, we first regress the dummy variable of being employed on a set of education and age dummy variables, and the results are reported in Table 5. For males, the higher the educational attainment, the higher is the employment rate. Being a junior-high-school graduate reduces the employment rate by 10.7 percentage points compared with being a high-school graduate, and the difference is statistically significant. Vocational-school education increases the 
employment rate by 1.6 percentage points compared with being a high-school graduate, and the estimated effect is statistically significant. In contrast, graduating from junior/technical college does not increase the employment rate in a statistically significant way. University and post-graduate education increase the employment rate. Considering the fact that higher-educational institutions are concentrated in urban areas, the specifications, including 47 prefecture fixed effects are estimated for both sexes, but the inclusions of prefecture fixed effects virtually do not change the estimation results.

The difference of employment rates by educational background is more pronounced among females than among males. A junior-high-school graduate, on average, is 14.0 percentage points less likely to be employed than a high-school graduate. Meanwhile, graduating from tertiary educational institutions is strongly associated with a high employment rate. A vocational-school graduate is 10.8 percentage points more likely to be employed than a highschool graduate. The differences are 8.0 percentage points for a junior/technical college graduate, 16.0 percentage points for a university graduate, and 25.4 percentage points for a graduate-school graduate. Allowing for 47 prefecture fixed effects virtually does not change the estimation results. We should keep in mind as a caveat that parts of these differences are attributable to differences in unobserved characteristics of individuals with different educational backgrounds, such as preference toward employment and innate ability in market production. The large difference in employment probability, however, arguably points to the particular importance of tertiary education as a determinant of offered wage for young females.

We next estimate the Mincerian wage function with detailed educational category variables with and without prefecture fixed effects. Hourly wage rate is calculated from the annual earnings divided by the annual hours worked; both annual earnings and annual hours worked are constructed from responses in intervals. The regression results reported in Table 6 indicate that the inclusion of prefecture fixed effects does not change the estimation results significantly. There is virtually zero difference in male wages between vocational-school 
graduates and high-school graduates, but there is about a 15\% difference in female wages for these two groups. The wage differential between junior/technical-college graduates and highschool graduates is about $18 \%$ for females but about $5 \%$ for males. A possible reason why post-high school non-university education rewards females more than males is that education is closely related to vocation training for licensed occupations, particularly occupations in the health industry, such as nurses, for females (Hamanaka (2009)). The wage differential between university graduates and high-school graduates is about $18 \%$ for males and $31 \%$ for females. The wage differential between post-graduate-school graduates and high-school graduates is large for both sexes: $38 \%$ for males and $40 \%$ for females.

The wage differentials between high-school graduates and vocational school or junior/technical college graduates are larger for females than for males. To analyze the reason behind the sex differences, Tables 7 and 8 tabulate the top 10 occupations among youth by educational background for both sexes, along with each composition rate and average hourly wage. A large fraction of male high-school graduates engage in blue-collar occupations, such as automobile driver, metal worker, civil engineering laborer, assembler, and package deliverer. The high fraction of blue-collar workers among male high-school graduates results in higher wages to compensate for the occupations' harsh labor conditions through the compensating wage differentials. The graduates of vocational school or junior/technical college are more likely to engage in low-skilled white collar jobs, such as clerical worker or sales person. In addition, they are likely to be in specialist jobs, such as automobile or general machine mechanic, system engineer, cook, or hairdresser. At any rate, the systematic occupational difference between high-school graduates and non-university tertiary educational institutions' graduates well explains why the wage differentials are small for those groups.

About $17 \%$ of male university graduates work as clerical workers. This fact represents the difficulty of classifying white-collar jobs among youth, because some, if not all, of them work for companies as candidates for managerial positions. The same discussion applies to sales-related jobs, which consist of about $23 \%$ of all jobs held by young male university 
graduates. Some may involve repetitive sales of simple products, whereas others may involve the sales of complicated and specialized products. The finest occupational code available in ESS 2007 does not allow us to step in the detailed analysis, but the higher average wage of male university graduates than high-school graduates within an occupation suggest that university graduates engage in tasks requiring skills. Among clerical workers, for example, male university graduates earn about $18 \%$ more per hour than male high-school graduates. The occupations of workers with post-graduate degrees are quite distinct from those of other educational backgrounds. All the top listed occupations are scientists and engineers, except for clerical workers. The concentration of post-graduate degree holders in the occupations of scientists and engineers explains their higher earnings.

The female occupational choices by educational background are strikingly different from those of males, as tabulated in Table 8. About $47 \%$ of young female high-school graduates engage in low-skilled white-collar jobs, such as clerical worker, sales person, or accounting clerk. In contrast, one quarter of female vocational-school graduates work as nurses. They are also likely to be in other health-service-related jobs or personal-care jobs. The occupations of graduates from junior/technical colleges are not so distinct from the occupations of highschool graduates, as a very large fraction of them work as clerical workers and sales persons; meanwhile a significant fraction of them work as nurses or care workers. The concentration of vocational school or junior/technical college graduates in licensed jobs, such as nurses or care workers would explain their significantly higher wages and employment rates compared with high-school graduates. The large fraction of female university graduates are white-collar workers, such as clerical workers, accounting clerks, or sales persons. Similar to male workers, the classification "clerical workers" includes jobs involving a wide range of tasks: from simple, repetitive tasks to complex and comprehensive ones. Among female clerical workers, university graduates earn $18 \%$ more than high-school graduates, reflecting that university graduates tend to engage in jobs requiring higher skills. The occupational composition of female post-graduate degree holders is more diverse than that of males; they are likely to 
work as clerical workers or teachers, as well as scientists and engineers.

Overall, the sex difference in the occupational compositions by educational background explains the sex difference in the wage differentials by educational background. Male highschool graduates tend to work in blue-collar jobs that are well compensated because of their harsh physical environments, whereas female high-school graduates tend to work in lowlevel white-collar jobs. Male vocational school or junior/technical college graduates work in variety of fields, but their female counterparts are concentrated in health- or care-related jobs that generally require occupational licenses. These systematic sex differences explain why the return to non-university tertiary education is apparently higher among females than among males.

\section{Conclusion}

This paper overviews the change of youth employment since the early 1980s. Without question, the employment rate, wage rate, and employment stability among youth has deteriorated significantly in Japan in the two-decade-long economic malaise. At the same time, Japan has kept a relatively high employment rate among youth between the ages of 25 and 29 compared with other developed countries. We demonstrate that the educational upgrading of youth in Japan has helped adapt to the demand increase for skilled workers arguably caused by skill-biased technological change and deepening international dependence of economic activities. Many previous studies, such as Abe (2010) and Hamanaka (2013), point

to the importance of education as a determinant of youth's labor-market success, but we are the first to comprehensively analyze the role of educational upgrading on employment status of youth based on large-scale government microdata, the Employment Status Survey, covering the long period between 1982 and 2007.

The analysis reveals that Japanese youth of both sexes upgraded their educational backgrounds substantially between 1982 and 2007. The fraction of male youth, aged between 25 and 29, who completed tertiary education increased from $38 \%$ in 1982 to $60 \%$ in 2007 . The 
corresponding figure for females increased from $32 \%$ to $66 \%$. The relative supply increase of educated workers matched the relative demand increase for them, as suggested by the increase in the fraction of youth in high-skilled occupations. Stable or slightly increasing pecuniary returns to tertiary education also corroborate with the demand growth for skilled workers. A counterfactual analysis indicates that without the youth educational upgrading, their employment rates would have decreased by $15 \%$ for males and $25 \%$ for females. All industries almost uniformly have absorbed educated workers, implying that the relative demand for educated workers has grown in all industries. The detailed analysis relying on 2007 data reveals that vocational schools play an important role by giving youth access to tertiary education. The payoff for attending vocational schools seems high, in terms of both employment opportunity and wages, particularly for females, because its graduates are likely to engage in licensed occupations, such as nurses. The return to post-graduate education also turns out to be high, because those degree holders are likely to work as specialists, such as scientists and engineers for both sexes and school teachers for females.

Given that prime minister Shinzo Abe points to continuous innovation and deepening international dependence of the economy through participation in the Trans-Pacific Partnership (TPP) as a part of the policy package of the third arrow of Abenomics, the continuous skill upgrading of Japanese youth is indispensable. Expanding opportunities for tertiary education for a wider range of youth while keeping the quality of education high, however, is a big challenge, because the quality control of tertiary education is a complicated issue. Simply leaving the issues of quantity expansion and quality improvement of tertiary education, including both vocational education and higher education, to the market would not be an appropriate policy option, because the literature has long recognized that the market for tertiary education is different from the ordinary goods market on several grounds. ${ }^{7}$

\footnotetext{
${ }^{7}$ The literature points to following points as the differences between tertiary education and the ordinary goods. First, externality of education to society is recognized widely (see Acemoglu and Angrist (2001) for example). Second, since each individual experiences higher education usually at most once, it is classified as an "experience good" rather than a "search good" (Nelson (1970)). In addition, higher education has been viewed as a prime example of a market with asymmetric information (Akerlof (1970)). The principalagent view is developed in the insurance market context by Spence and Zeckhauser (1971), but it has
} 
Higher-education regulation need to be discussed in ways that squarely face these complicated and delicate issues, as successful control of tertiary education should form the basis for the success of the supply-side policies in Abenomics.

Another issue highlighted in study is the heterogeneity of youth labor-market experience over the last three decades by educational attainment. The evidence in this paper corroborates with a relative demand increase for more educated workers and a relative demand decrease for less educated workers in the long run. Therefore, the answer to the question posed in the subtitle "Are all Japanese youth ready for structural reforms?" is clearly negative, because we do not expect demand growth for low-skill workers in the long run. In this regard, we need to pay particular attention to the dismal labor-market outcomes among junior-high-school graduates, including high-school dropouts: the labor force that consists of 6 to $7 \%$ of a cohort's total labor force. Opening up the Japanese labor market to unskilled immigrants should be carefully discussed in relation to its impact on the labor-market outcomes of those workers. ${ }^{8}$ Also, policies to reduce high-school drop outs, such as tuition subsidies for needy families, should be carefully assessed. ${ }^{9}$

As a final remark, we note two important limitations of our study as caveats. First, as the fraction of youth proceeding to higher education increases, the ability of students attending these institutions and the quality of these institutions are likely to become more heterogeneous. The increased heterogeneity within an educational category should be reflected in the increased heterogeneity of wage within a category. The ESS analysis sample employed in

been used in the higher education context as well. Better information provision, therefore, may be good for consumers and may lead to a set of more effective producers. Some have argued, however, that the problem of higher education is not so much informational asymmetry but imperfect information (Stiglitz (2000)). Both government and consumers may have imperfect information about the true quality of academic programs. In addition, faculty members may not possess full information (Dill and Soo (2004)). Third, Rothschild and White (1995) argue that higher education is the premier example of the many services that provide outputs that depend on other customer inputs. Moreover, Brickley and Zimmerman (2001) point to the dual objectives of professors, teaching and research, which complicate the mechanism to provide them with incentives.

${ }^{8}$ See Nakamura, Naito, Kambayashi, Kawaguchi, and Machikita (2009) for comprehensive studies in Japan

${ }^{9}$ Akabayashi and Araki (2011) showed that increasing tuition support is effective in preventing the dropout of private high-school students on nonacademic tracks. 
this study, however, does not serve as the best data source for a variance analysis because of its crude measure of hourly wage rate constructed from three categorical variables: annual earnings, weekly hours worked, and weeks worked in the previous year. The measurement error in hourly wage introduced unavoidably in the process of the variable construction is less innocuous in the variance analysis than in the mean analysis in the manuscript. Yamada and Kawaguchi (2014) document the change of within-group variance of hourly wage accurately imputed from the Basic Survey on Wage Structure. The within-group wage variance increased between 1991 and 2008 among high-school graduates, junior-college graduates and university graduates. It is left for future research to relate the observed increase of wage variance within a group with the increase in the unobserved heterogeneity among university graduates or the increase in the heterogeneity in the quality of university education.

Second, we analyzed labor markets of male and female youth separately throughout the paper without paying much attention to the interaction between the two markets. The substitutability or complementarity between them in the production process creates an interdependence of labor demands for each sex. In addition, changes in marriage behavior and social norms on the division of labor create an interdependence of labor supplies for each sex. The interdependence of both labor demand and supply for each sex affects the equilibriums in both labor markets in complex ways. Comprehensive analysis of the interdependence of male and female labor markets is left for future research.

\section{References}

Abe, M., and S. Ohta (2001): "Fluctuations in unemployment and industry labor markets," Journal of the Japanese and International Economies, 15, 437-464.

ABE, N. (2011a): "Youth employment status and permanent income risk," Discussion Paper 2011-J03, National Institute of Population and Social Security Research, in Japanese language. 
ABE, Y. (2010): "Equal Employment Opportunity Law and the gender wage gap in Japan: A cohort analysis," Journal of Asian Economics, 21(2), 142-155.

(2011b): "The Equal Employment Opportunity Law and labor force behavior of women in Japan," Journal of the Japanese and International Economies, 25(1), 39-55.

ABE, Y., And K. TAmada (2010): "Regional patterns of employment changes of lesseducated men in Japan," Japan and the World Economy, 22, 69-79.

Acemoglu, D., And J. Angrist (2001): "How Large are Human-Capital Externalities? Evidence from Compulsory-Schooling Laws," in NBER Macroeconomics Annual 2000, Volume 15, NBER Chapters, pp. 9-74. National Bureau of Economic Research, Inc.

Ahn, S., K. Fukao, and K. Ito (2008): "The impact of outsourcing on the Japanese and South Korean labor markets: International outsourcing of intermediate inmputs and assembly in East Asia," Columbia Business School Working Paper Series No. 260.

AkAbayashi, H., AND H. Araki (2011): "Do education vouchers prevent dropout at private high schools? Evidence from Japanese policy changes," Journal of the Japanese and International Economies, 25(3), 183 - 198.

Akerlof, G. A. (1970): “The Market for 'Lemons': Quality Uncertainty and the Market Mechanism," The Quarterly Journal of Economics, 84(3), 488-500.

Asano, H., T. Ito, and D. Kawaguchi (2013): "Why Has the Fraction of Nonstandard Workers Increased? A Case Study of Japan," Scottish Journal of Political Economy, 60(4), $360-389$.

Barro, R. J., And J. W. LEe (2013): "A new data set of educational attainment in the world, 1950-2010," Journal of Development Economics, 104, 184-198.

Berman, E., J. Bound, and Z. Griliches (1994): "Changes in the demand for skilled 
labor within U. S. manufacturing industries," Quarterly Journal of Economics, 109, 367398.

Berman, E., J. Bound, and S. Machin (1998): "Implications of skill-biased technological change: International evidence," Quarterly Journal of Economics, 113, 1245-1279.

Borjas, G. J., And V. A. RAmey (1995): "Foreign competition, market power and wage inequality," Quarterly Journal of Economics, 110, 1075-1110.

Bound, J., And G. Johnson (1992): "Changes in the structure of wages in the 1980s: An evaluation of alternative explanations," American Economic Review, 82, 371-392.

Bound, J., And S. Turner (2007): "Cohort crowding: How resources affect collegiate attainment," Journal of Public Economics, 91(5-6), 877-899.

Brickley, J. A., And J. L. Zimmerman (2001): "Changing incentives in a multitask environment: evidence from a top-tier business school," Journal of Corporate Finance, $7(4), 367-396$.

Dill, D. D., AND M. Soo (2004): "Transparency and quality in higher education markets," in Markets in Higer Education, pp. 61-85. Springer.

Feenstra, R. C., And G. H. Hanson (1996): "Globalization, outsourcing, and wage inequality," American Economic Review Papers and Proceedings, 86, 240-245.

(1999): "The impact of outsourcing and high-technology capital on wages: Estimates for the United States, 1979-1990," Quarterly Journal of Economics, 114, 907-940.

GendA, Y. (2006): A Nagging Sense of Job Insecurity:The New Reality Facing Japanese Youth. I-House Press.

(2007): "Reexamination of Youth Nonemployment," Japanese Journal of Labour Studies, 567, 97-112, in Japanese language. 
HamanaKa, J. (2009): "Employment of vocational school graduates," Japanese Journal of Labour Studies, 588, 34-43, in Japanese language.

(2013): The utility of education. Keiso Shobo, Tokyo, in Japanese language.

Johnson, G. E. (1997): "Changes in earnings inequality: The role of demand shifts," Journal of Economic Perspectives, 11, 41-54.

Kambayashi, R., and T. Kato (2013): "Good Jobs, Bad Jobs, and the Great Recession: Lessons from Japans Lost Decade," PRIMCED Discussion Paper Series 41, Institute of Economic Research, Hitotsubashi University.

Katz, L. F., And K. M. Murphy (1992): "Changes in Relative Wages, 1963-1987: Supply and Demand Factors," The Quarterly Journal of Economics, 107(1), 35-78.

Kawaguchi, D., And Y. Mori (2014): "Winning the race against technology," Discussion paper, Research Institute of Economy Trade and Industry and Bank of Japan.

Korenman, S., and D. Neumark (2000): "Cohort Crowding and Youth Labor Markets (A Cross-National Analysis)," in Youth Employment and Joblessness in Advanced Countries, NBER Chapters, pp. 57-106. National Bureau of Economic Research, Inc.

Krueger, A. B. (1997): "Labor market shifts and the price puzzle revisited," NBER Working Paper 5924.

KurodA, S. (2003): "Analysis of changes in Japan's unemployment rate using gross flor data," Monetary and Economic Studies, 21, 69-104.

Levy, F., And R. J. Murnane (1996): "With what skills are computers a complement?," American Economic Review Papers and Proceedings, 86, 258-262.

Ling, C., And H. Miyamoto (2012): "Cross worker flows and unemployment dynamics in Japan," Journal of the Japanese and International Economies, 26, 44-61. 
Machin, S., And J. VAn ReEnen (1998): "Technology and changes in skill structure evidence from seven OECD countries," Quarterly Journal of Economics, 113, 1215-1244.

Mitani, N. (2008): Young Workers in the Global Economy: Job Challenges in North America, Europe and Japanchap. Youth Employment in Japan after the 1990s Bubble Burst., pp. 109 - 134. Cheltenham, U.K. and Northampton, Mass.: Elgar, Kobe U.

Miyamoto, H. (2010): "Cyclical behavior of unemployment and job vacancies in Japan," Journal of the Japanese and International Economies, 23, 214-225.

Mryoshi, K. (2008): "Maleemale wage differentials in Japan," Japan and the World Economy, 20(4), $479-496$.

Morikawa, M. (2012): "Postgraduate Education and Human Capital Productivity in Japan," Discussion papers 12009, Research Institute of Economy, Trade and Industry (RIETI).

NAGAO, Y. (2008): "Functions of vocational schools and changes of the students' socioeconomic backgrounds," Journal of the Japan Society of Educational Sociology, 83, 85-106, in Japanese language.

Nakamura, J., H. Naito, R. Kambayashi, D. Kawaguchi, and T. Machikita (2009): Foreign Labor Force in Japan. Nihon Keizai Shinbun Publishing, in Japanese language.

Nelson, P. (1970): "Information and Consumer Behavior," Journal of Political Economy, $78(2), 311-29$.

Nickell, S., L. Nunziata, and W. Ochel (2005): "Unemployment in the OECD since the 1960s. What Do we know?," The Economic Journal, 115, 1-27.

Rothschild, M., And L. J. White (1995): "The Analytics of the Pricing of Higher 
Education and Other Services in Which the Customers Are Inputs," Journal of Political Economy, 103(3), 573-86.

Sachs, J. D., And H. J. Shatz (1994): "Trade and Jobs in U.S. Manufacturing," Brookings Papers on Economic Activity, 1, 1-69.

SAKurai, K. (2001): "Biased technological change and Japanese manufacturing employment," Journal of the Japanese and International Economies, 15, 298-322. (2004): "How does trade affect the labor market?" Japan and the World Economy, $16,139-161$.

Spence, M., And R. Zeckhauser (1971): "Insurance, Information, and Individual Action," American Economic Review, 61(2), 380-87.

Stiglitz, J. E. (2000): Economics of the Public Sector. W W Norton \& Company Incorporated.

YAmADA, K., AND D. KaWAGUChI (2014): "The changing and unchanged nature of inequality and seniority in Japan," Discussion paper, Singapore Management University. 
Figure 1: Japan's Unemployment Rate, 1968-2012 (Source: OECD)

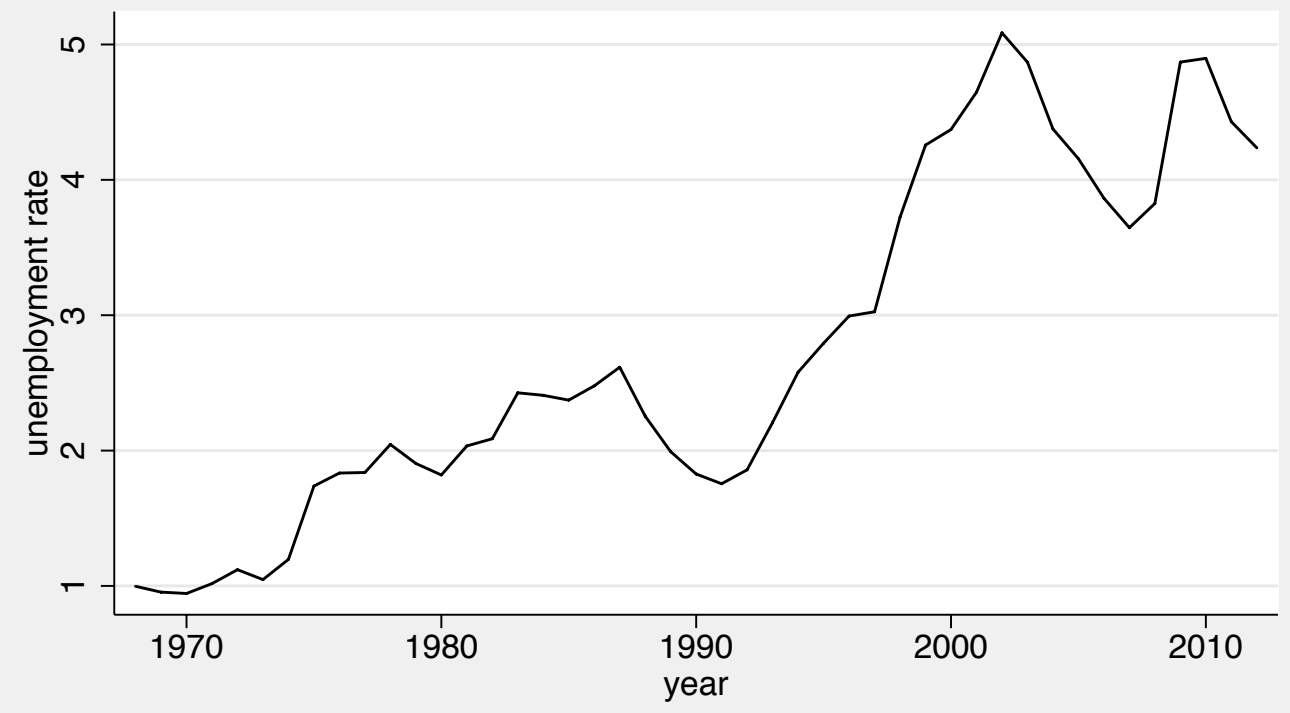

Figure 2: Japan's Unemployment Rate, Age 25-29, 1984-2012 (Source: OECD)

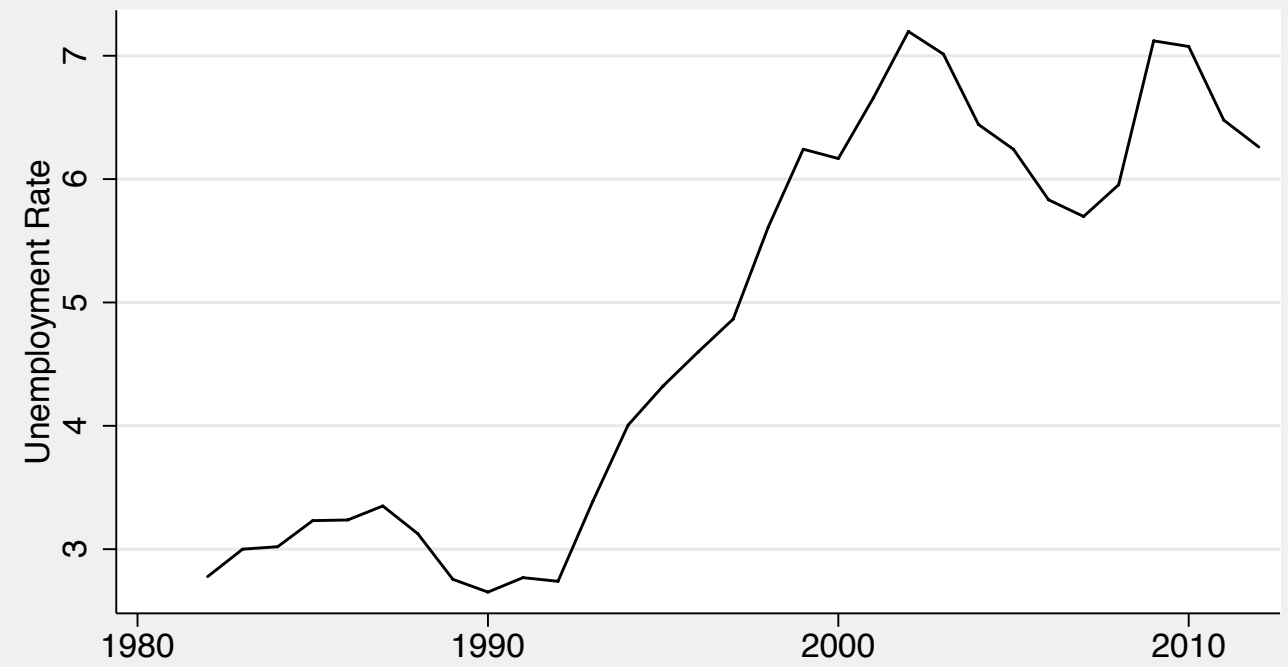


Figure 3: Unemployment Rate, Age 25-29, 1984-2012 (Source: OECD)



Figure 4: Employment-to-Population Ratio for Men, Age 25-29, 1984-2012 (Source: OECD)

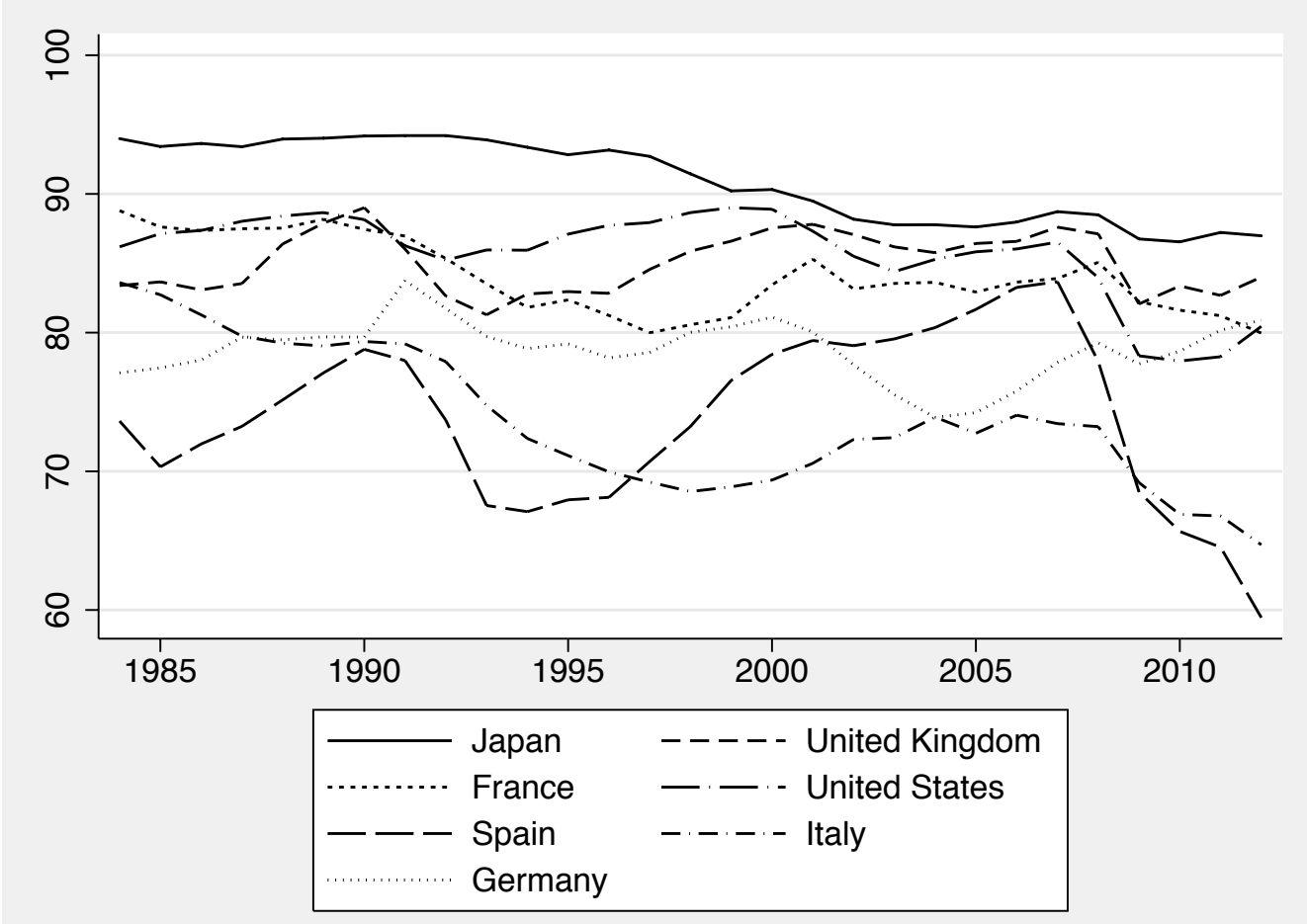


Figure 5: Employment-to-Population Ratio for Women, Age 25-29, 1984-2012 (Source: OECD)

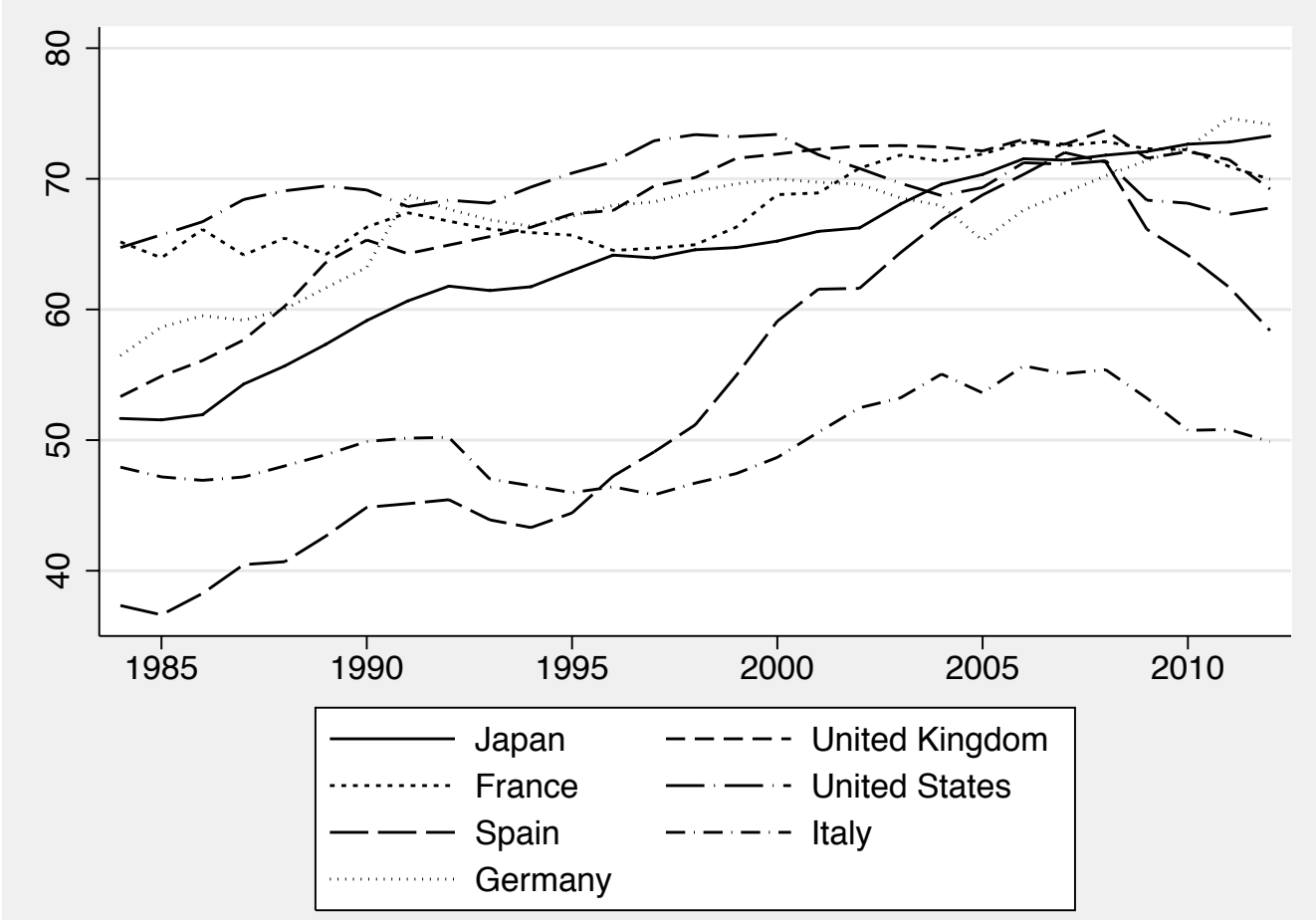


Figure 6: Proportion of Those Completing Tertiary Education for Men, Age 25-29, 19802010 (Source: Barro and Lee, 2013)

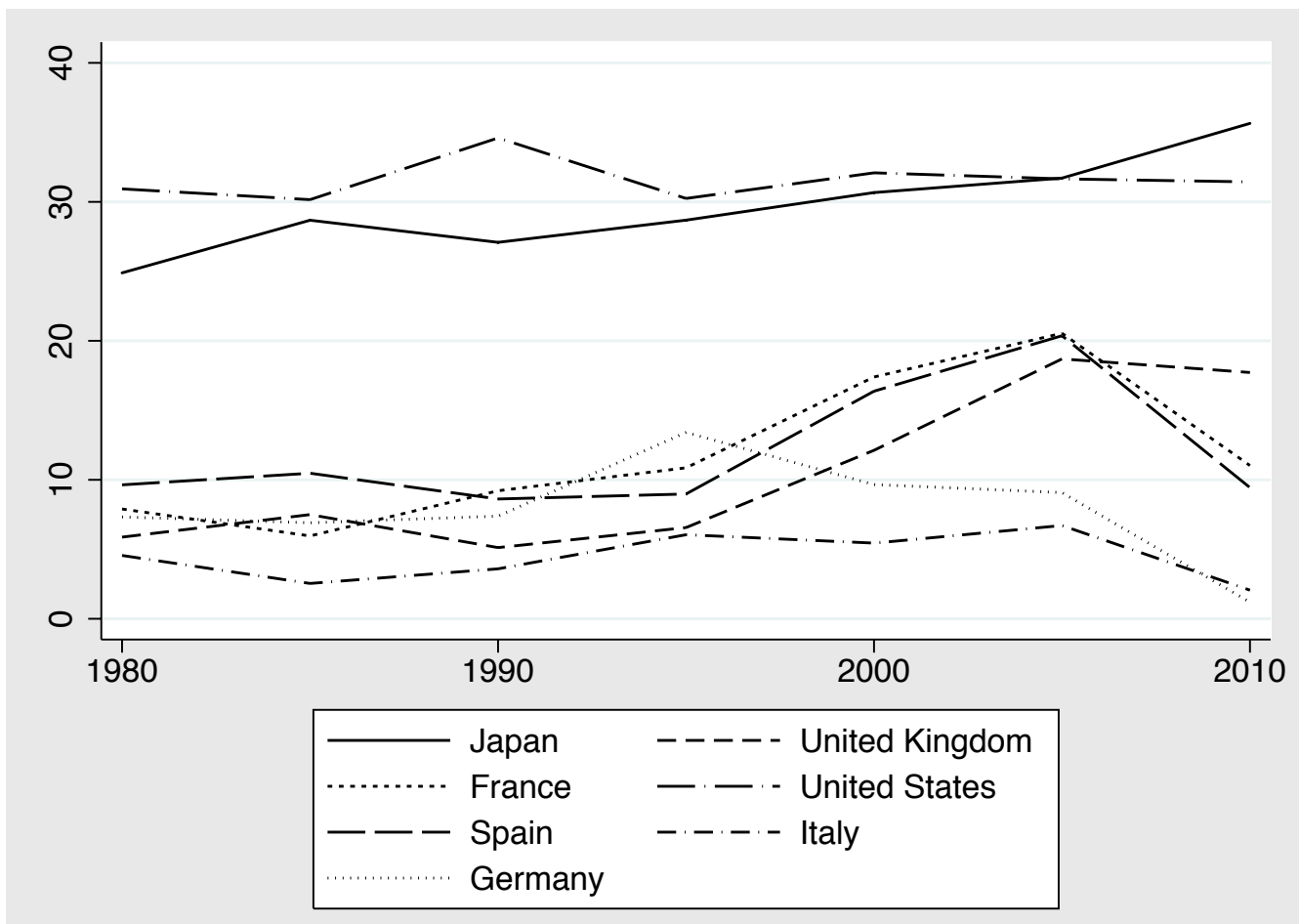


Figure 7: Proportion of Those Completing Tertiary Education for Women, Age 25-29, 19802010 (Source: Barro and Lee, 2013)

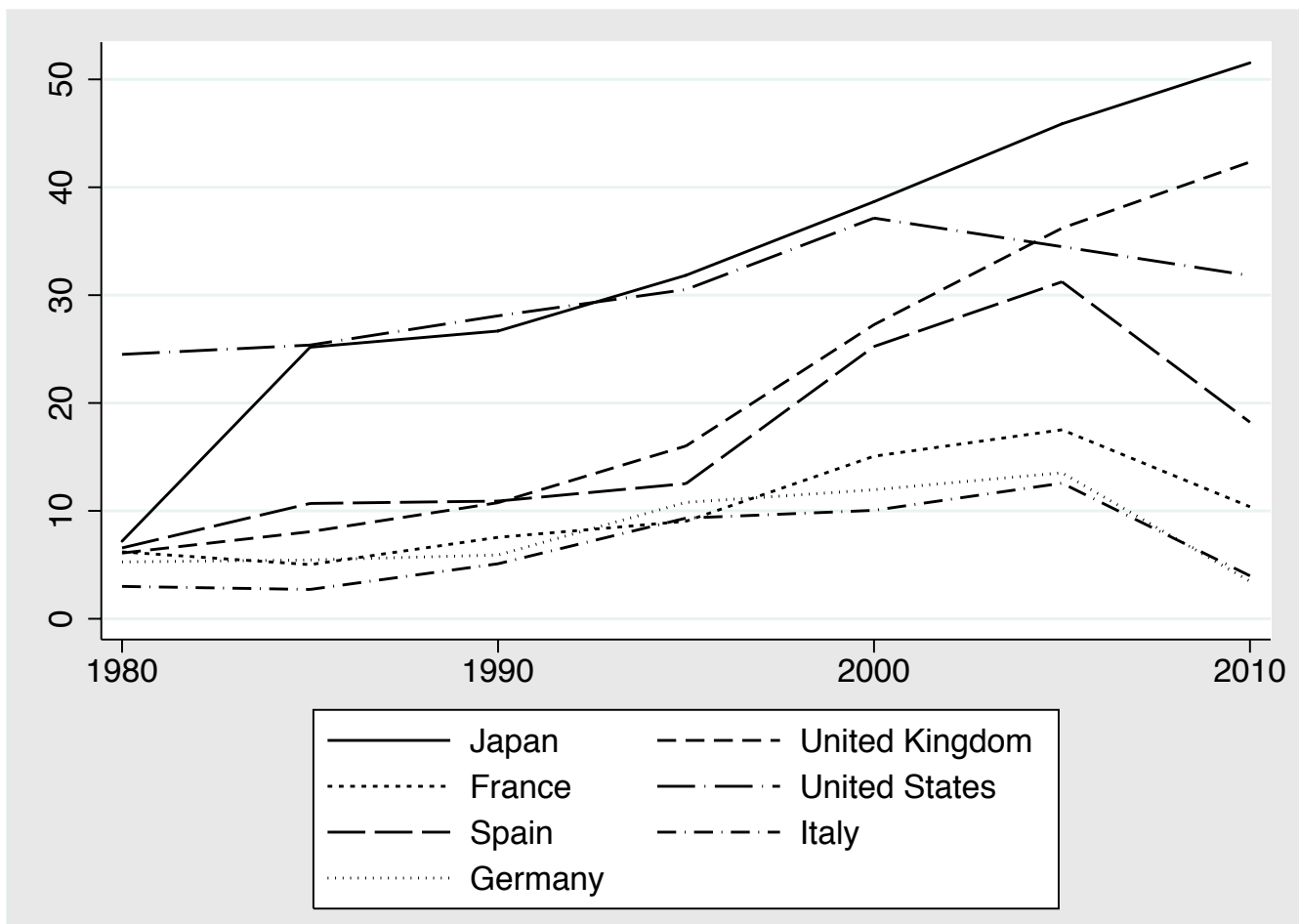


Figure 8: Composition of Age 25-29 as a Percentage of All Ages for Men, 1984-2012 (Source: OECD)

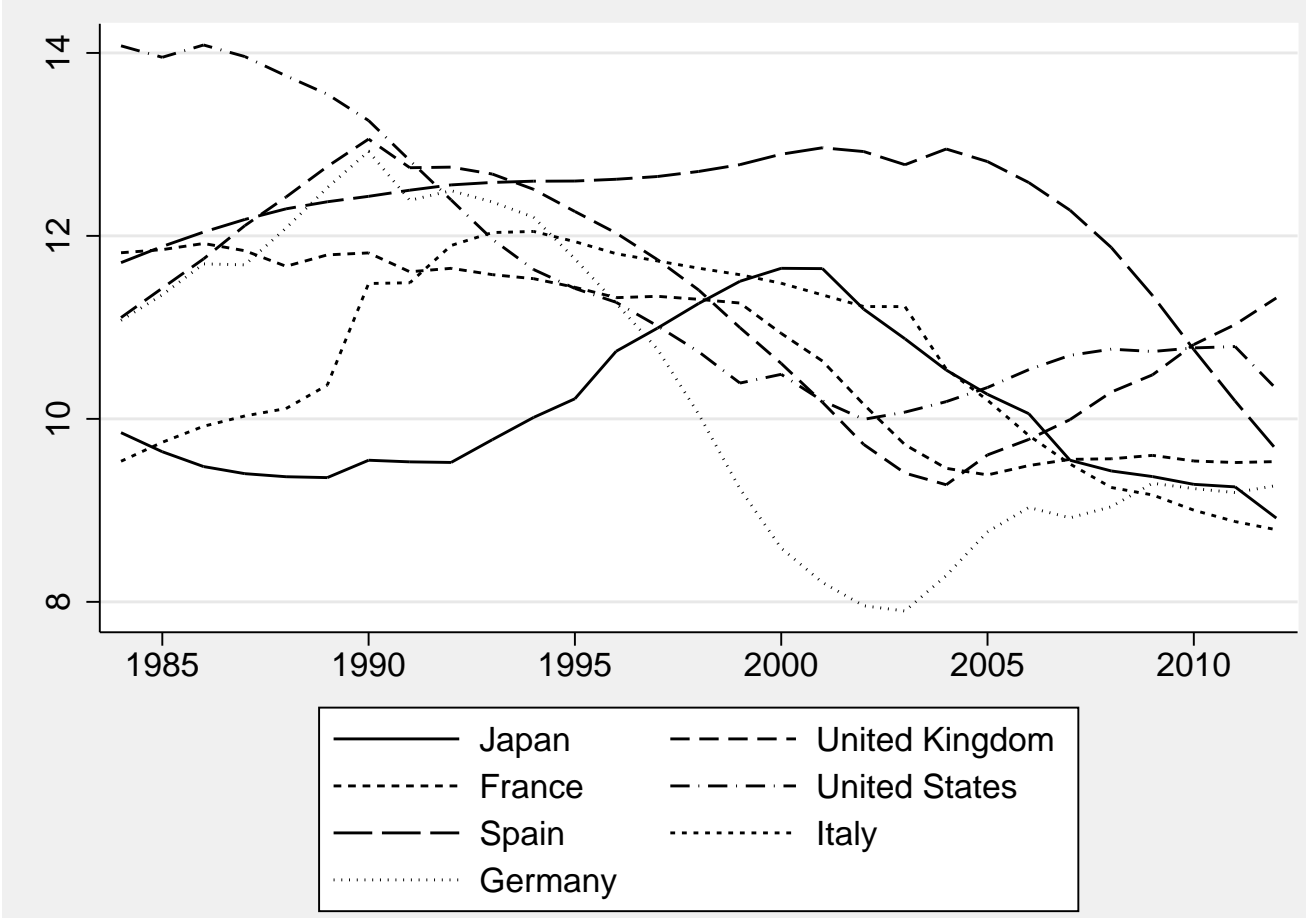


Figure 9: Composition of Age 25-29 as a Percentage of All Ages for Women, 1984-2012 (Source: OECD)

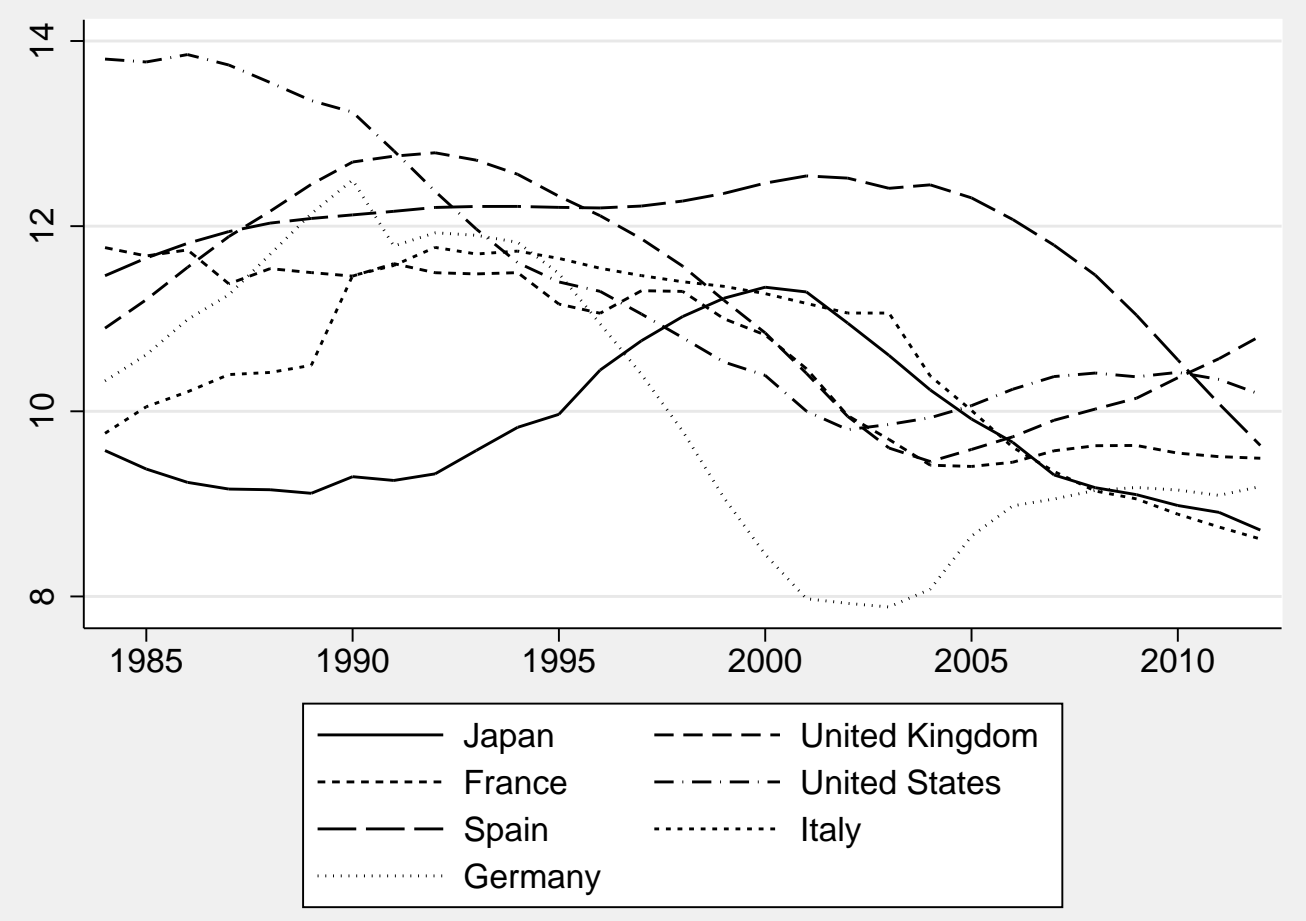


Figure 10: Employment rate of males age 25-29, 1982-2007
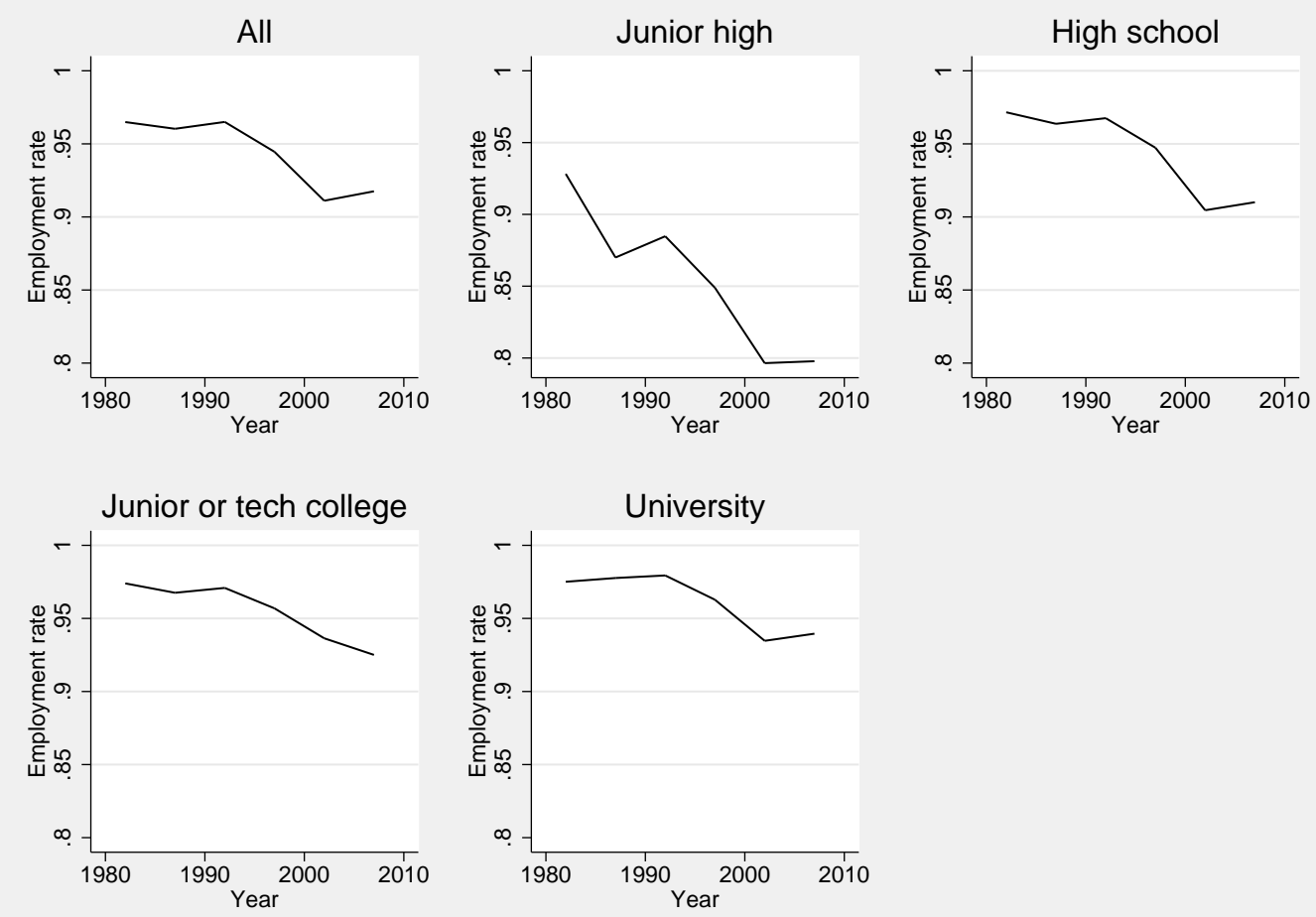

Figure 11: Educational composition of males, age 25-29, 1982-2007
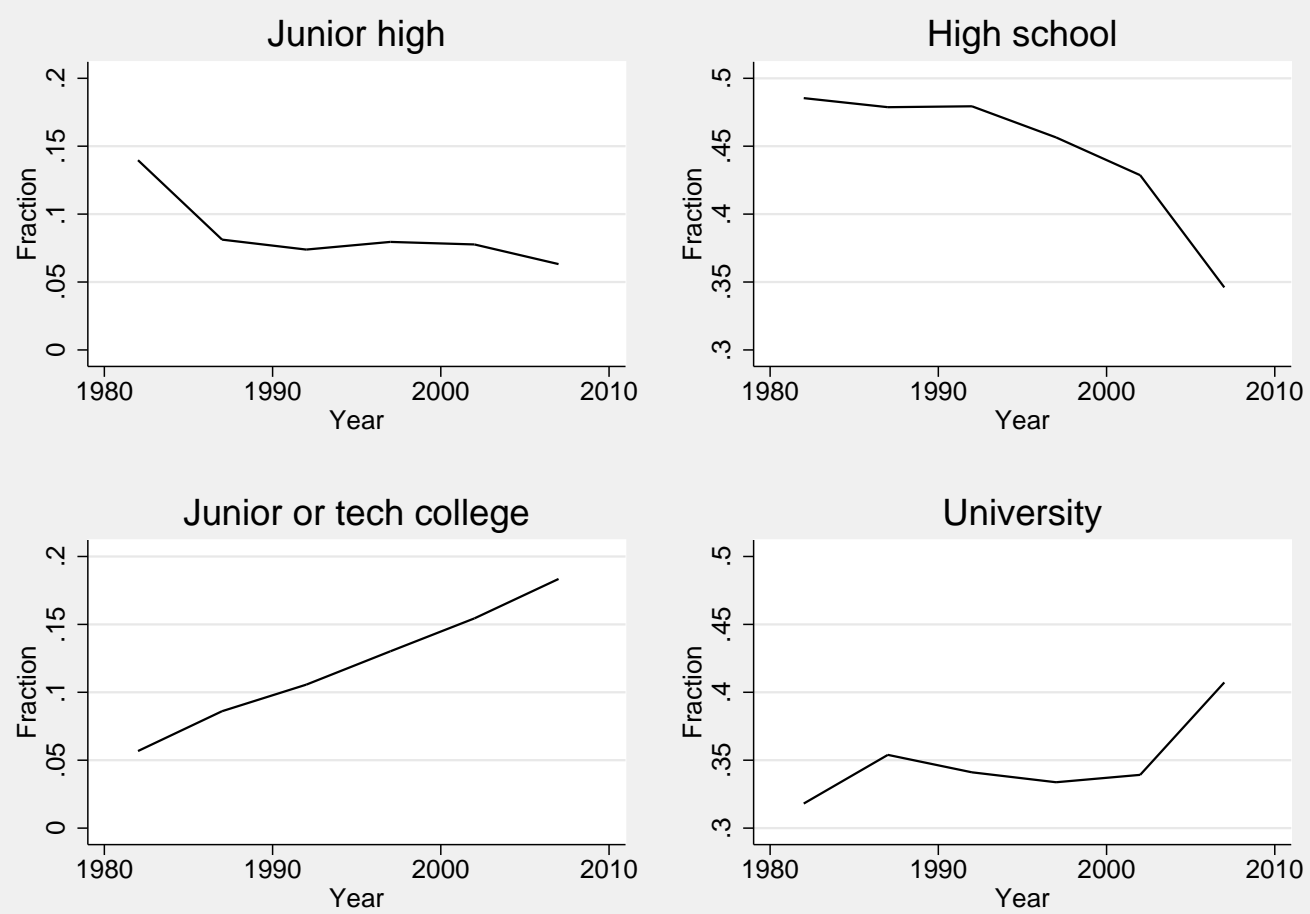
Figure 12: Employment rate of females age 25-29, 1982-2007
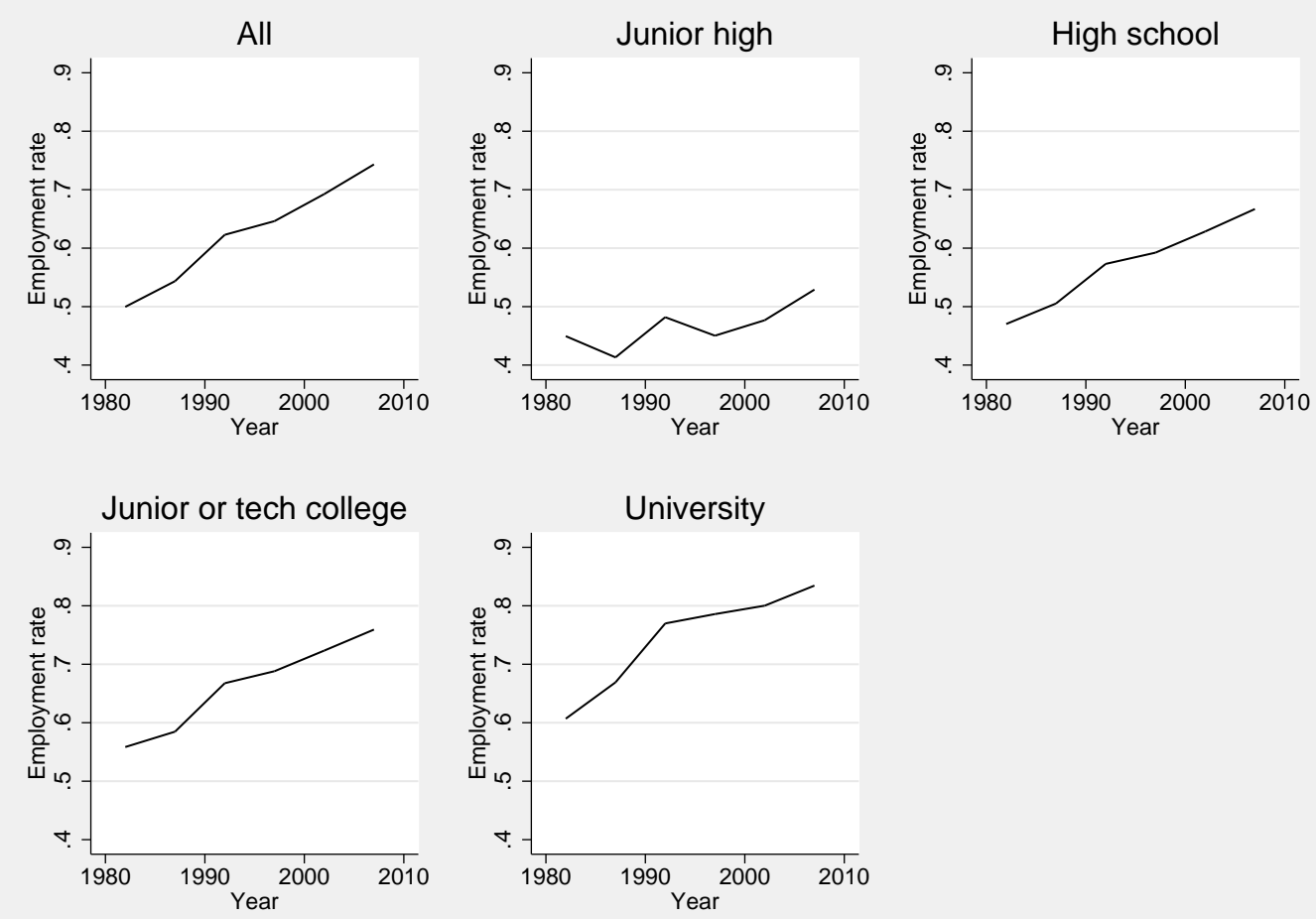

Figure 13: Educational composition of females age 25-29, 1982-2007
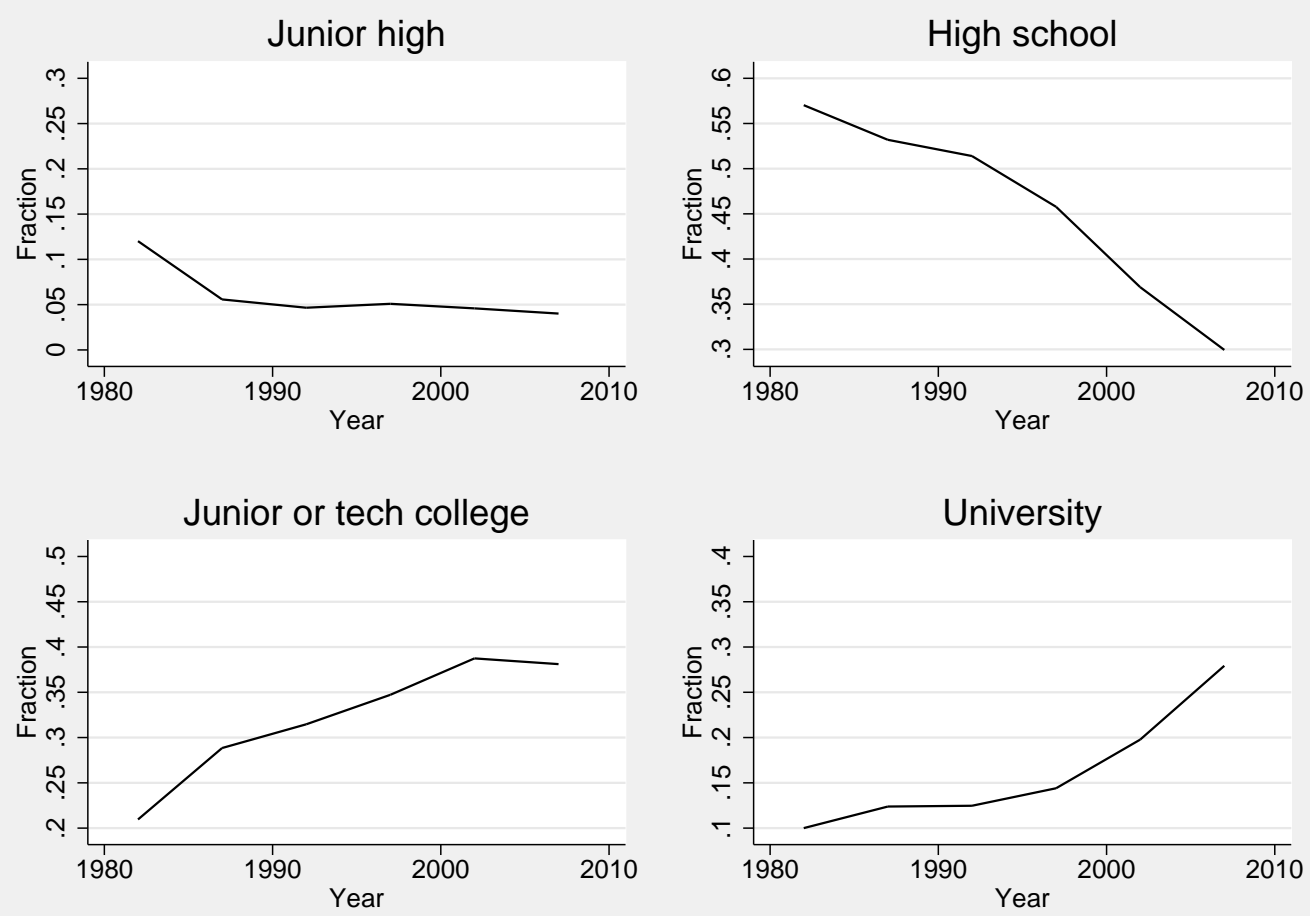
Figure 14: Counterfactual evolution of the employment rate of youth ages 25-29, 1982-2007
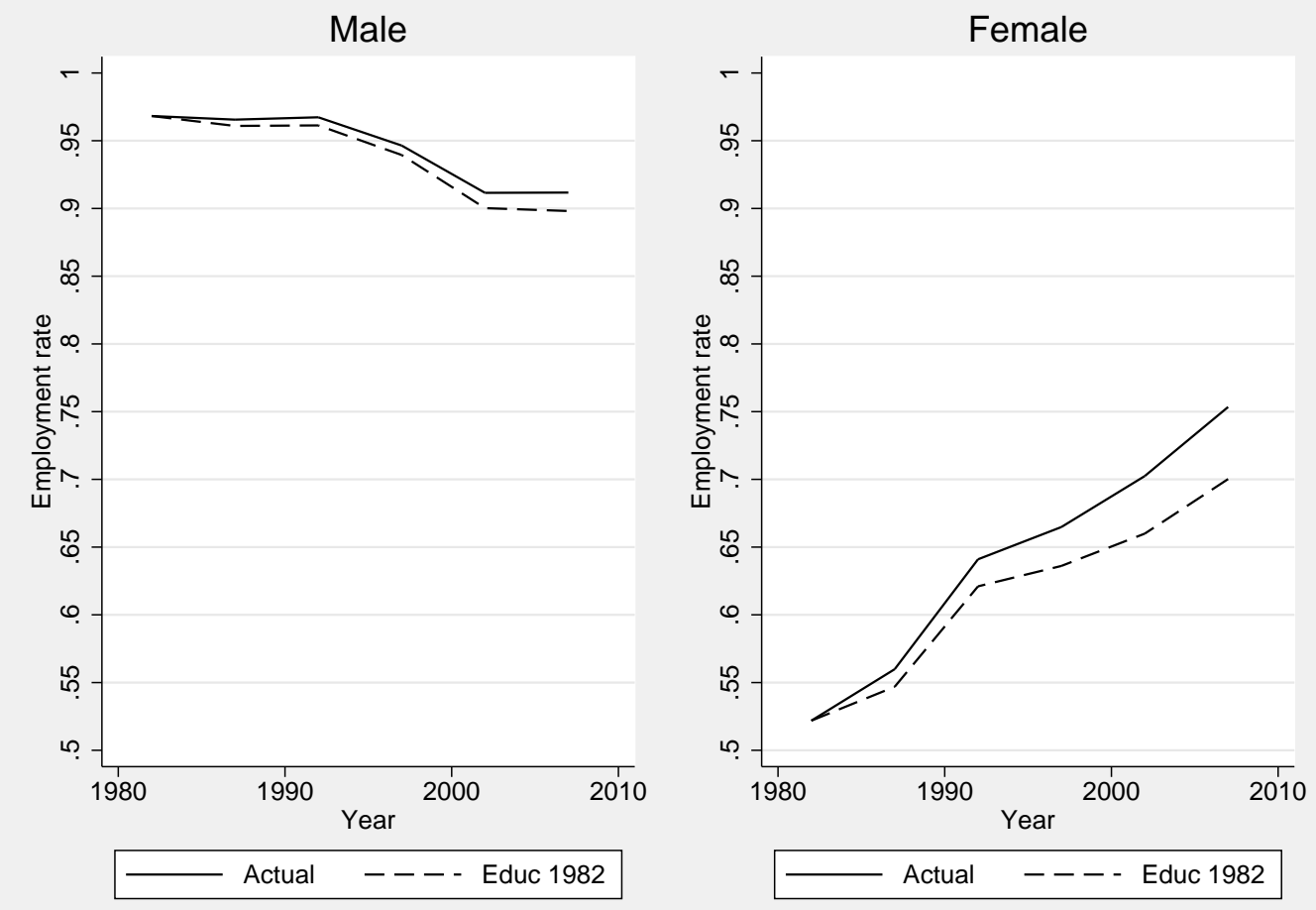

Actual: $e \hat{m} p_{t}^{t}=\bar{x}^{t} \hat{\beta}_{t}$; Education 1982: êmp $p_{t}^{1982}=\bar{x}^{1982} \hat{\beta}_{t}$

Figure 15: Fraction of non-regular employees among all workers, ages 25-29, 1982-2007
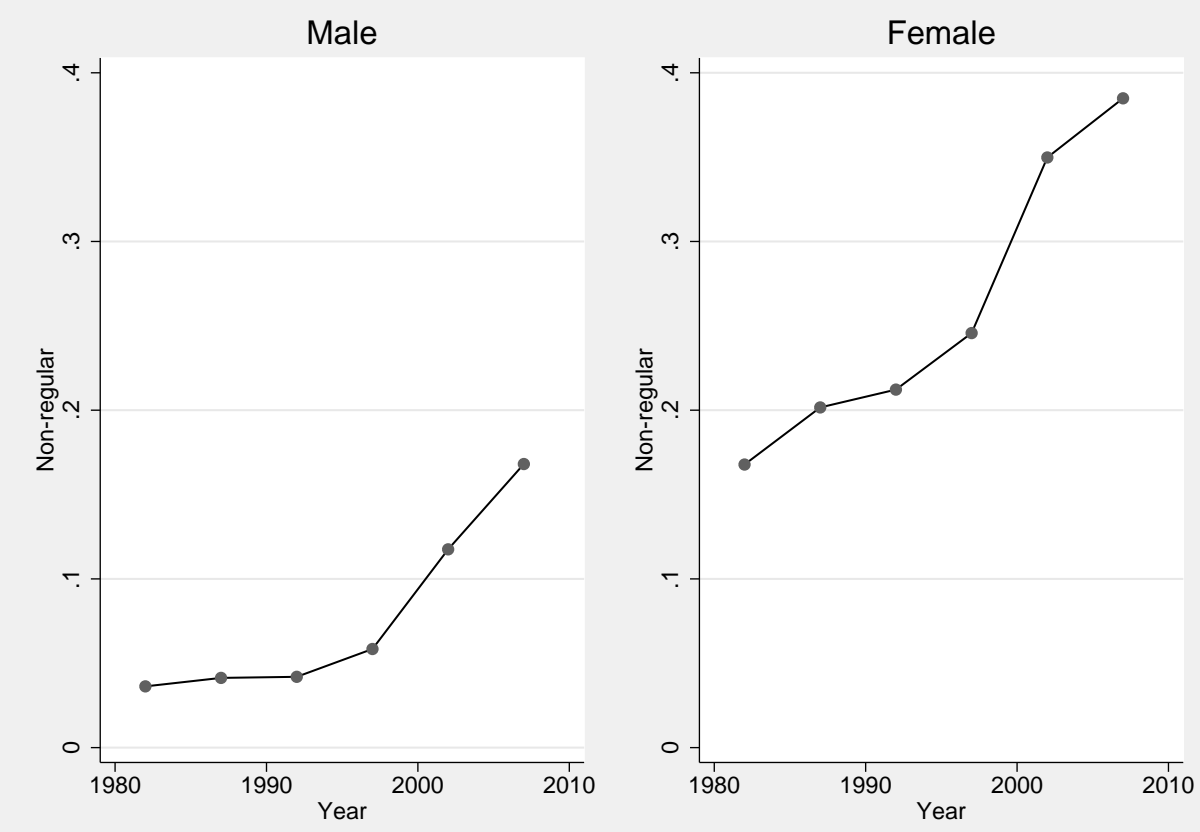
Figure 16: Occupational composition of employment, age 25-29, 1982-2007
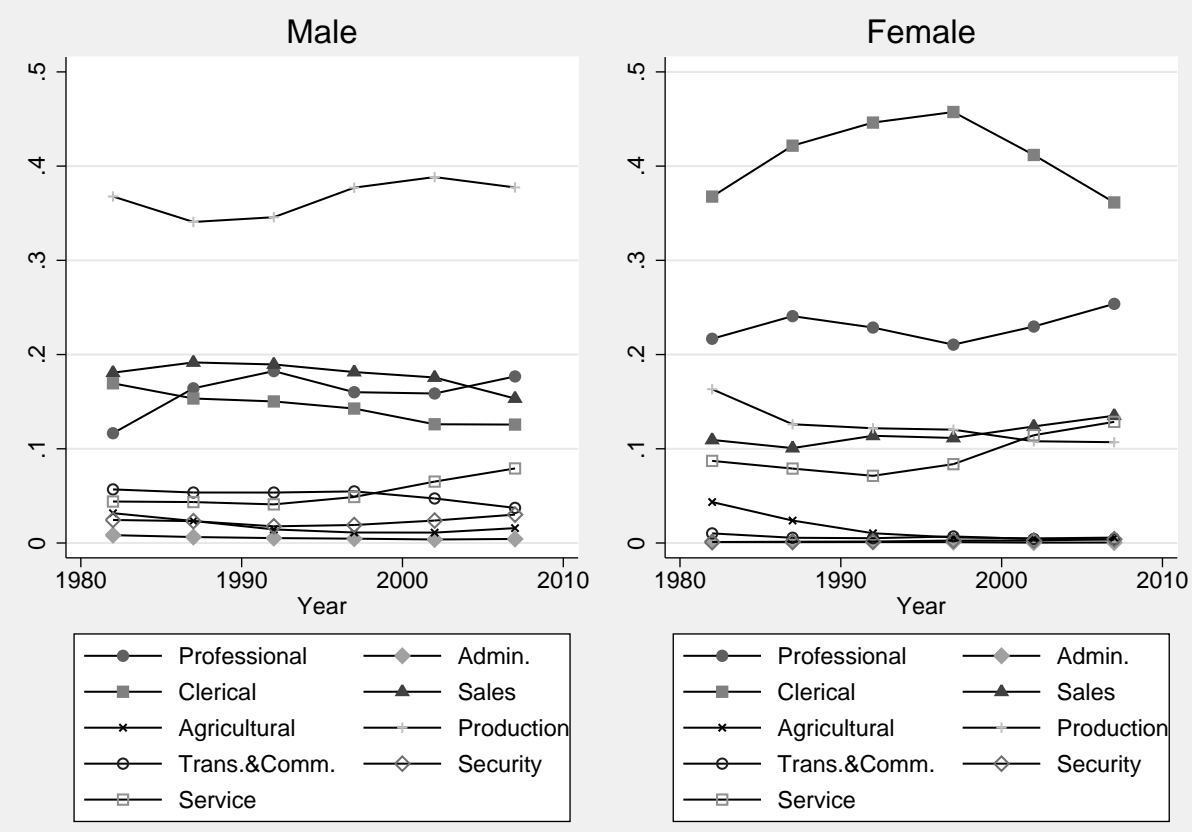

Figure 17: Occupational growth by the initial hourly wage, age 25-29, 1982-2007

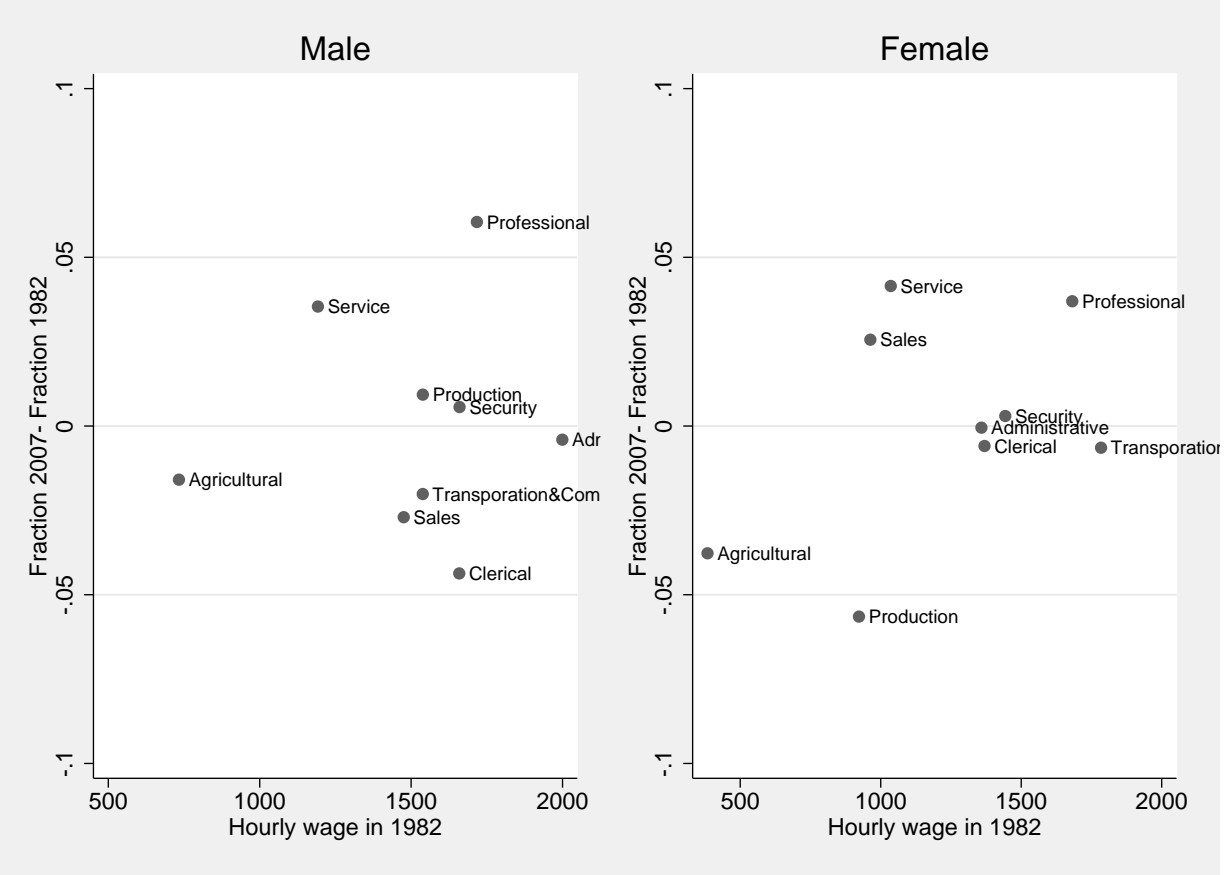

Note: Hourly wage rate in 1982 is calculated based on annual earnings and annual hours worked. 
Figure 18: Log real wage of males age 25-29 by education, 1981-2012
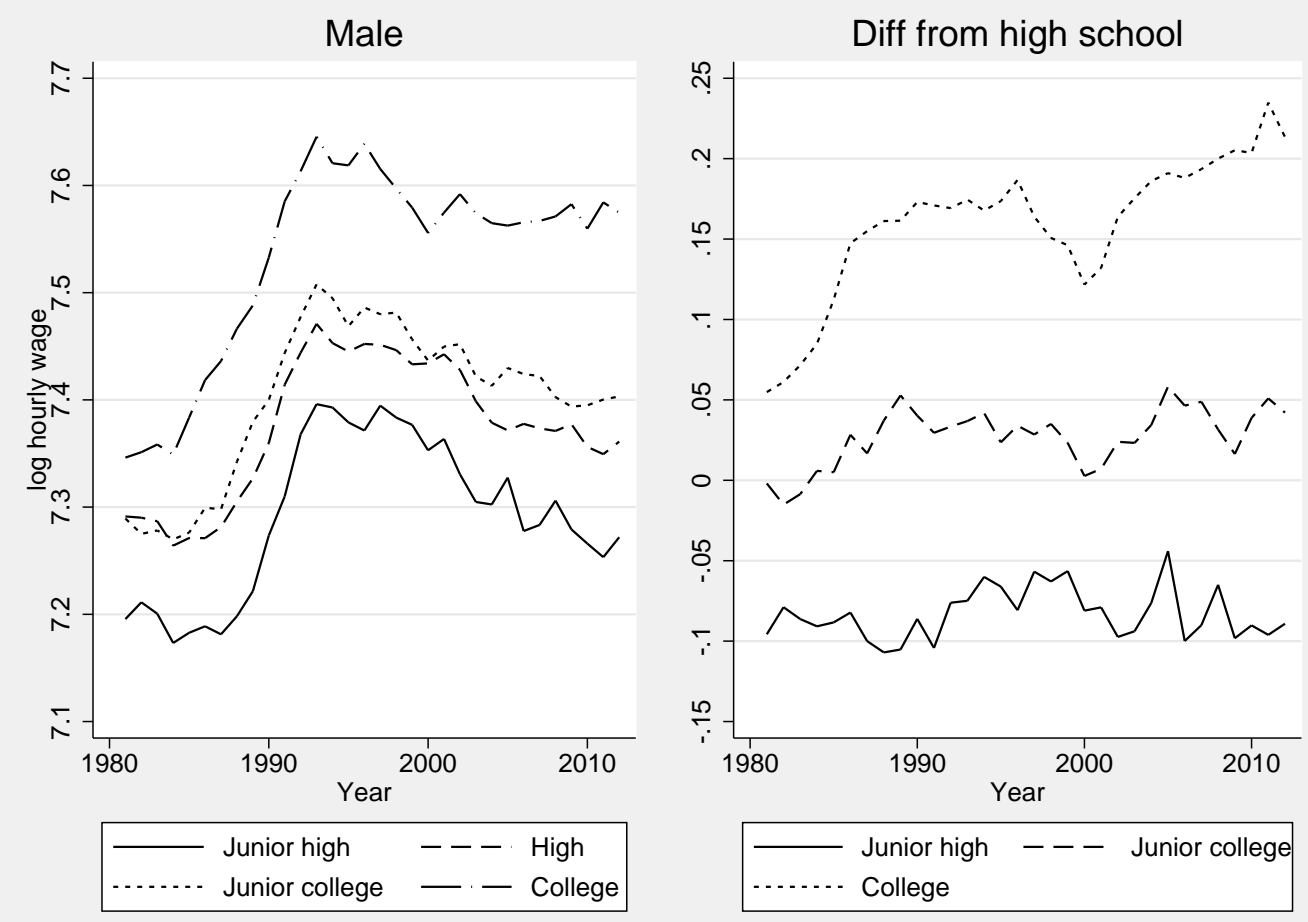

Note: Full-time workers. All wages are deflated to 2010 price using consumer price index. 
Figure 19: Log real wage of females age 25-29 by education, 1981-2012
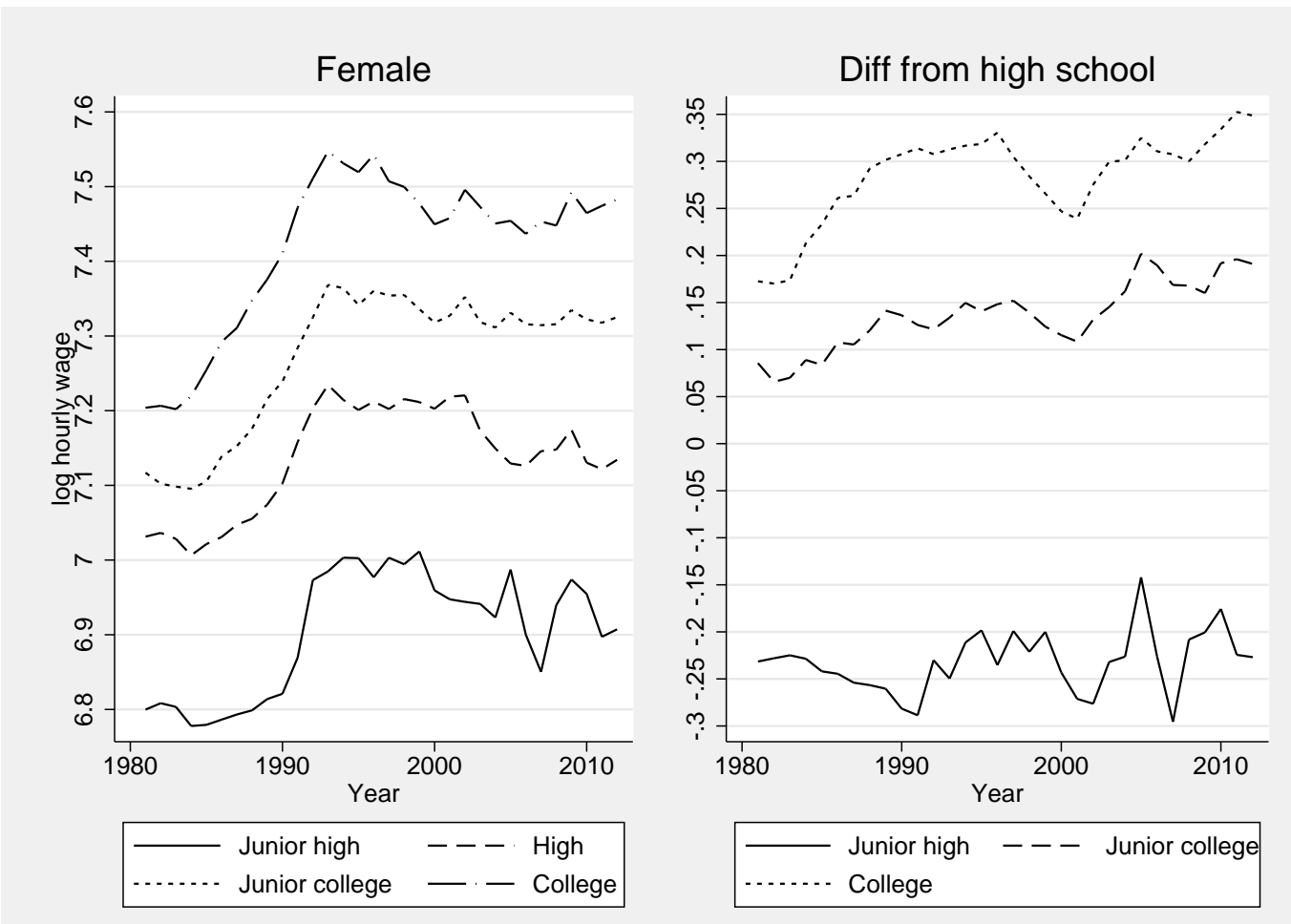

Note: Full-time workers. All wages are deflated to 2010 price using consumer price index. 
Table 1: The fraction of non-regular employees, age 25-29

\begin{tabular}{|c|c|c|c|c|c|c|c|c|}
\hline \multirow[b]{2}{*}{ Education } & \multirow{2}{*}{$\begin{array}{c}\text { Male } \\
\text { JH }\end{array}$} & \multicolumn{7}{|c|}{ Female } \\
\hline & & $\mathrm{H}$ & $\mathrm{JC}$ & Univ & $\mathrm{JH}$ & $\mathrm{H}$ & $\mathrm{JC}$ & Univ \\
\hline 1987 & $\begin{array}{c}0.017 \\
(0.011)\end{array}$ & $\begin{array}{c}0.010 \\
(0.003)\end{array}$ & $\begin{array}{c}0.010 \\
(0.009)\end{array}$ & $\begin{array}{c}0.005 \\
(0.003)\end{array}$ & $\begin{array}{c}0.059 \\
(0.028)\end{array}$ & $\begin{array}{l}0.042 \\
(0.008)\end{array}$ & $\begin{array}{l}0.039 \\
(0.011)\end{array}$ & $\begin{array}{c}0.010 \\
(0.016)\end{array}$ \\
\hline 1992 & $\begin{array}{c}0.013 \\
(0.011)\end{array}$ & $\begin{array}{c}0.013 \\
(0.003)\end{array}$ & $\begin{array}{c}0.007 \\
(0.008)\end{array}$ & $\begin{array}{c}0.003 \\
(0.003)\end{array}$ & $\begin{array}{c}0.165 \\
(0.028)\end{array}$ & $\begin{array}{l}0.052 \\
(0.008)\end{array}$ & $\begin{array}{l}0.030 \\
(0.010)\end{array}$ & $\begin{array}{l}-0.010 \\
(0.015)\end{array}$ \\
\hline 1997 & $\begin{array}{c}0.032 \\
(0.011)\end{array}$ & $\begin{array}{c}0.032 \\
(0.003)\end{array}$ & $\begin{array}{c}0.018 \\
(0.007)\end{array}$ & $\begin{array}{c}0.020 \\
(0.003)\end{array}$ & $\begin{array}{c}0.243 \\
(0.025)\end{array}$ & $\begin{array}{l}0.102 \\
(0.008)\end{array}$ & $\begin{array}{l}0.046 \\
(0.009)\end{array}$ & $\begin{array}{c}0.013 \\
(0.014)\end{array}$ \\
\hline 2002 & $\begin{array}{c}0.167 \\
(0.015)\end{array}$ & $\begin{array}{c}0.096 \\
(0.004)\end{array}$ & $\begin{array}{c}0.080 \\
(0.008)\end{array}$ & $\begin{array}{c}0.074 \\
(0.005)\end{array}$ & $\begin{array}{c}0.375 \\
(0.026)\end{array}$ & $\begin{array}{l}0.230 \\
(0.009)\end{array}$ & $\begin{array}{l}0.150 \\
(0.010)\end{array}$ & $\begin{array}{c}0.106 \\
(0.014)\end{array}$ \\
\hline 2007 & $\begin{array}{c}0.191 \\
(0.019)\end{array}$ & $\begin{array}{c}0.176 \\
(0.006)\end{array}$ & $\begin{array}{c}0.175 \\
(0.011)\end{array}$ & $\begin{array}{c}0.096 \\
(0.005)\end{array}$ & $\begin{array}{c}0.429 \\
(0.027)\end{array}$ & $\begin{array}{l}0.342 \\
(0.010)\end{array}$ & $\begin{array}{l}0.182 \\
(0.011)\end{array}$ & $\begin{array}{c}0.103 \\
(0.014)\end{array}$ \\
\hline 26 & $\begin{array}{l}-0.007 \\
(0.014)\end{array}$ & $\begin{array}{l}-0.008 \\
(0.004)\end{array}$ & $\begin{array}{c}0.003 \\
(0.010)\end{array}$ & $\begin{array}{l}-0.007 \\
(0.005)\end{array}$ & $\begin{array}{c}0.063 \\
(0.027)\end{array}$ & $\begin{array}{l}0.033 \\
(0.008)\end{array}$ & $\begin{array}{l}0.021 \\
(0.008)\end{array}$ & $\begin{array}{c}0.019 \\
(0.011)\end{array}$ \\
\hline 27 & $\begin{array}{l}-0.008 \\
(0.013)\end{array}$ & $\begin{array}{l}-0.016 \\
(0.004)\end{array}$ & $\begin{array}{l}-0.025 \\
(0.009)\end{array}$ & $\begin{array}{l}-0.021 \\
(0.004)\end{array}$ & $\begin{array}{c}0.104 \\
(0.027)\end{array}$ & $\begin{array}{l}0.043 \\
(0.008)\end{array}$ & $\begin{array}{l}0.045 \\
(0.008)\end{array}$ & $\begin{array}{l}0.027 \\
(0.011)\end{array}$ \\
\hline 28 & $\begin{array}{c}-0.004 \\
(0.014)\end{array}$ & $\begin{array}{l}-0.021 \\
(0.004)\end{array}$ & $\begin{array}{c}-0.034 \\
(0.009)\end{array}$ & $\begin{array}{l}-0.025 \\
(0.004)\end{array}$ & $\begin{array}{c}0.084 \\
(0.027)\end{array}$ & $\begin{array}{l}0.072 \\
(0.008)\end{array}$ & $\begin{array}{l}0.067 \\
(0.009)\end{array}$ & $\begin{array}{c}0.036 \\
(0.012)\end{array}$ \\
\hline 29 & $\begin{array}{l}-0.011 \\
(0.013)\end{array}$ & $\begin{array}{l}-0.035 \\
(0.004)\end{array}$ & $\begin{array}{r}-0.043 \\
(0.009)\end{array}$ & $\begin{array}{l}-0.029 \\
(0.004)\end{array}$ & $\begin{array}{c}0.103 \\
(0.026)\end{array}$ & $\begin{array}{l}0.093 \\
(0.008)\end{array}$ & $\begin{array}{l}0.046 \\
(0.009)\end{array}$ & $\begin{array}{c}0.029 \\
(0.012)\end{array}$ \\
\hline Constant & $\begin{array}{c}0.112 \\
(0.011)\end{array}$ & $\begin{array}{c}0.052 \\
(0.003)\end{array}$ & $\begin{array}{c}0.052 \\
(0.008)\end{array}$ & $\begin{array}{c}0.042 \\
(0.004)\end{array}$ & $\begin{array}{c}0.259 \\
(0.022)\end{array}$ & $\begin{array}{l}0.166 \\
(0.007)\end{array}$ & $\begin{array}{l}0.135 \\
(0.009)\end{array}$ & $\begin{array}{c}0.153 \\
(0.013)\end{array}$ \\
\hline $\begin{array}{l}R^{2} \\
N\end{array}$ & $\begin{array}{c}0.04 \\
13,298\end{array}$ & $\begin{array}{c}0.04 \\
82,214\end{array}$ & $\begin{array}{c}0.05 \\
19,664\end{array}$ & $\begin{array}{c}0.03 \\
54,615\end{array}$ & $\begin{array}{c}0.11 \\
4,955\end{array}$ & $\begin{array}{c}0.06 \\
52,307\end{array}$ & $\begin{array}{c}0.03 \\
40,876\end{array}$ & $\begin{array}{c}0.02 \\
20,677\end{array}$ \\
\hline
\end{tabular}

Note: Heteroskedasticity robust standard errors are reported in the parentheses. JH stands for junior-high-school graduates, H stands for high-school graduates, JC stands for Junior College graduates, Univ stands for university graduates. 
Table 2: Industrial composition and the fraction of workers with tertiary education, males age 25-29

\begin{tabular}{lcccccc}
\hline \hline & 1982 & 1987 & 1992 & 1997 & 2002 & 2007 \\
\hline Composition & & & & & & \\
Primary & 0.03 & 0.03 & 0.02 & 0.01 & 0.01 & 0.02 \\
Construction & 0.13 & 0.11 & 0.11 & 0.13 & 0.14 & 0.11 \\
Manufacturing & 0.24 & 0.25 & 0.27 & 0.25 & 0.23 & 0.24 \\
Retail\&Wholesale & 0.22 & 0.22 & 0.19 & 0.20 & 0.20 & 0.19 \\
Finance & 0.04 & 0.04 & 0.05 & 0.04 & 0.03 & 0.03 \\
Transportation\&Communication & 0.08 & 0.08 & 0.09 & 0.09 & 0.13 & 0.13 \\
Public Utility & 0.01 & 0.01 & 0.01 & 0.01 & 0.01 & 0.01 \\
Service & 0.18 & 0.21 & 0.22 & 0.22 & 0.22 & 0.24 \\
Government & 0.07 & 0.05 & 0.04 & 0.04 & 0.04 & 0.05 \\
\hline Fraction of Tertiary Education & & & & & & \\
Primary & 0.14 & 0.19 & 0.25 & 0.28 & 0.36 & 0.41 \\
Construction & 0.21 & 0.29 & 0.28 & 0.29 & 0.29 & 0.35 \\
Manufacturing & 0.33 & 0.41 & 0.40 & 0.45 & 0.43 & 0.50 \\
Retail\&Wholesale & 0.39 & 0.42 & 0.45 & 0.48 & 0.54 & 0.63 \\
Finance & 0.67 & 0.74 & 0.79 & 0.82 & 0.82 & 0.88 \\
Transportation\&Communication & 0.19 & 0.19 & 0.22 & 0.28 & 0.55 & 0.64 \\
Public Utility & 0.27 & 0.33 & 0.41 & 0.51 & 0.41 & 0.49 \\
Service & 0.59 & 0.65 & 0.61 & 0.61 & 0.62 & 0.73 \\
Government & 0.47 & 0.54 & 0.58 & 0.60 & 0.60 & 0.80 \\
\hline \hline
\end{tabular}

Note: The upper panel reports the industrial composition of young workers that should add up to one for each year. The lower panel reports the fraction of tertiary-educated workers in each industry and in each year. The primary sector includes agriculture, fishery, forestry, and mining sectors. The government industry code moved the restaurant industry from Retail \& Wholesale to Service from 2002, but the figures above include the restaurant industry in the Retail\&Wholesale sector throughout. 
Table 3: Industrial composition and the fraction of workers with tertiary education, females age 25-29

\begin{tabular}{lcccccc}
\hline \hline & 1982 & 1987 & 1992 & 1997 & 2002 & 2007 \\
\hline Composition & & & & & & \\
Primary & 0.05 & 0.03 & 0.01 & 0.01 & 0.01 & 0.01 \\
Construction & 0.03 & 0.03 & 0.04 & 0.04 & 0.03 & 0.02 \\
Manufacturing & 0.20 & 0.19 & 0.19 & 0.18 & 0.14 & 0.13 \\
Retail\&Wholesale & 0.25 & 0.24 & 0.24 & 0.24 & 0.25 & 0.25 \\
Finance & 0.06 & 0.08 & 0.08 & 0.07 & 0.06 & 0.05 \\
Transportation\&Communication & 0.02 & 0.02 & 0.03 & 0.04 & 0.07 & 0.07 \\
Public Utility & 0.00 & 0.00 & 0.00 & 0.00 & 0.00 & 0.00 \\
Service & 0.35 & 0.39 & 0.39 & 0.39 & 0.41 & 0.45 \\
Government & 0.03 & 0.02 & 0.02 & 0.03 & 0.03 & 0.02 \\
\hline Fraction of Tertiary Education & & & & & & \\
Primary & 0.09 & 0.16 & 0.19 & 0.25 & 0.36 & 0.44 \\
Construction & 0.27 & 0.35 & 0.41 & 0.46 & 0.57 & 0.60 \\
Manufacturing & 0.17 & 0.30 & 0.34 & 0.43 & 0.46 & 0.52 \\
Retail\&Wholesale & 0.24 & 0.33 & 0.36 & 0.41 & 0.51 & 0.57 \\
Finance & 0.29 & 0.43 & 0.50 & 0.61 & 0.75 & 0.79 \\
Transportation\&Communication & 0.37 & 0.46 & 0.49 & 0.56 & 0.70 & 0.74 \\
Public Utility & 0.32 & 0.32 & 0.47 & 0.65 & 0.70 & 0.72 \\
Service & 0.60 & 0.65 & 0.65 & 0.67 & 0.73 & 0.81 \\
Government & 0.41 & 0.62 & 0.64 & 0.69 & 0.78 & 0.84 \\
\hline \hline
\end{tabular}

Note: The upper panel reports the industrial composition of young workers that should add up to one for each year. The lower panel reports the fraction of tertiary-educated workers in each industry and in each year. The primary sector includes agriculture, fishery, forestry, and mining sectors. The government industry code moved the restaurant industry from Retail \& Wholesale to Service from 2002, but the figures above include the restaurant industry in the Retail\&Wholesale sector throughout. 
Table 4: Distribution of detailed educational background, age 25-29, ESS, 2007

\begin{tabular}{lrr}
\hline \hline & Male & Female \\
\hline Junior high school & 0.05 & 0.03 \\
High school & 0.34 & 0.27 \\
Vocational school & 0.15 & 0.20 \\
Junior/technical college & 0.03 & 0.19 \\
University & 0.36 & 0.30 \\
Graduate school & 0.06 & 0.02 \\
\hline \hline
\end{tabular}

Note: Vocational school and junior/technical college are classified into a single category before 2007. University and graduate school are also classified into a single category before 2007.

Table 5: Determinants of employment, age 25-29, ESS, 2007

\begin{tabular}{lcccc}
\hline \hline & Male & Male & Female & Female \\
\hline Junior high school & -0.107 & -0.107 & -0.140 & -0.134 \\
& $(0.012)$ & $(0.012)$ & $(0.020)$ & $(0.019)$ \\
Vocational school & 0.016 & 0.015 & 0.108 & 0.108 \\
& $(0.006)$ & $(0.006)$ & $(0.010)$ & $(0.010)$ \\
Junior/technical college & 0.008 & 0.007 & 0.080 & 0.086 \\
& $(0.014)$ & $(0.014)$ & $(0.010)$ & $(0.010)$ \\
University & 0.025 & 0.022 & 0.160 & 0.162 \\
& $(0.005)$ & $(0.005)$ & $(0.009)$ & $(0.010)$ \\
Graduate school & 0.069 & 0.067 & 0.254 & 0.253 \\
& $(0.006)$ & $(0.006)$ & $(0.019)$ & $(0.020)$ \\
Age 26 & 0.008 & 0.008 & -0.028 & -0.028 \\
& $(0.008)$ & $(0.008)$ & $(0.010)$ & $(0.010)$ \\
Age 27 & 0.030 & 0.029 & -0.054 & -0.053 \\
& $(0.007)$ & $(0.007)$ & $(0.011)$ & $(0.011)$ \\
Age 28 & 0.027 & 0.026 & -0.082 & -0.081 \\
& $(0.007)$ & $(0.007)$ & $(0.011)$ & $(0.011)$ \\
Age 29 & 0.037 & 0.036 & -0.100 & -0.099 \\
& $(0.007)$ & $(0.007)$ & $(0.011)$ & $(0.011)$ \\
Prefecture F.E. & No & Yes & No & Yes \\
N & 25,805 & 25,805 & 26,695 & 26,695 \\
\hline \hline
\end{tabular}

Note: Average marginal effects of the probit estimates are reported. High-school graduate is set as the base category. 
Table 6: The determinants of log (hourly wage), age 25-29, ESS, 2007

\begin{tabular}{lcccc}
\hline \hline & Male & Male & Female & Female \\
\hline Junior high school & -0.102 & -0.117 & -0.025 & -0.033 \\
& $(0.023)$ & $(0.023)$ & $(0.042)$ & $(0.041)$ \\
Vocational school & -0.018 & -0.040 & 0.148 & 0.125 \\
& $(0.013)$ & $(0.013)$ & $(0.015)$ & $(0.015)$ \\
Junior/technical college & 0.046 & 0.040 & 0.184 & 0.158 \\
& $(0.024)$ & $(0.023)$ & $(0.015)$ & $(0.015)$ \\
University & 0.179 & 0.143 & 0.311 & 0.251 \\
& $(0.011)$ & $(0.011)$ & $(0.013)$ & $(0.013)$ \\
Graduate school & 0.382 & 0.333 & 0.469 & 0.404 \\
Age 26 & $(0.023)$ & $(0.022)$ & $(0.041)$ & $(0.041)$ \\
& 0.050 & 0.049 & 0.033 & 0.032 \\
Age 27 & $(0.014)$ & $(0.014)$ & $(0.015)$ & $(0.014)$ \\
\multirow{2}{*}{ Age 28 } & 0.110 & 0.109 & 0.060 & 0.058 \\
& $(0.014)$ & $(0.014)$ & $(0.015)$ & $(0.015)$ \\
Age 29 & 0.135 & 0.131 & 0.088 & 0.080 \\
Prefecture F.E. & $(0.014)$ & $(0.014)$ & $(0.015)$ & $(0.015)$ \\
$R^{2}$ & 0.180 & 0.178 & 0.133 & 0.136 \\
$N$ & $(0.014)$ & $(0.014)$ & $(0.017)$ & $(0.016)$ \\
\hline \hline
\end{tabular}

Note: High-school graduate is set as the base category. 


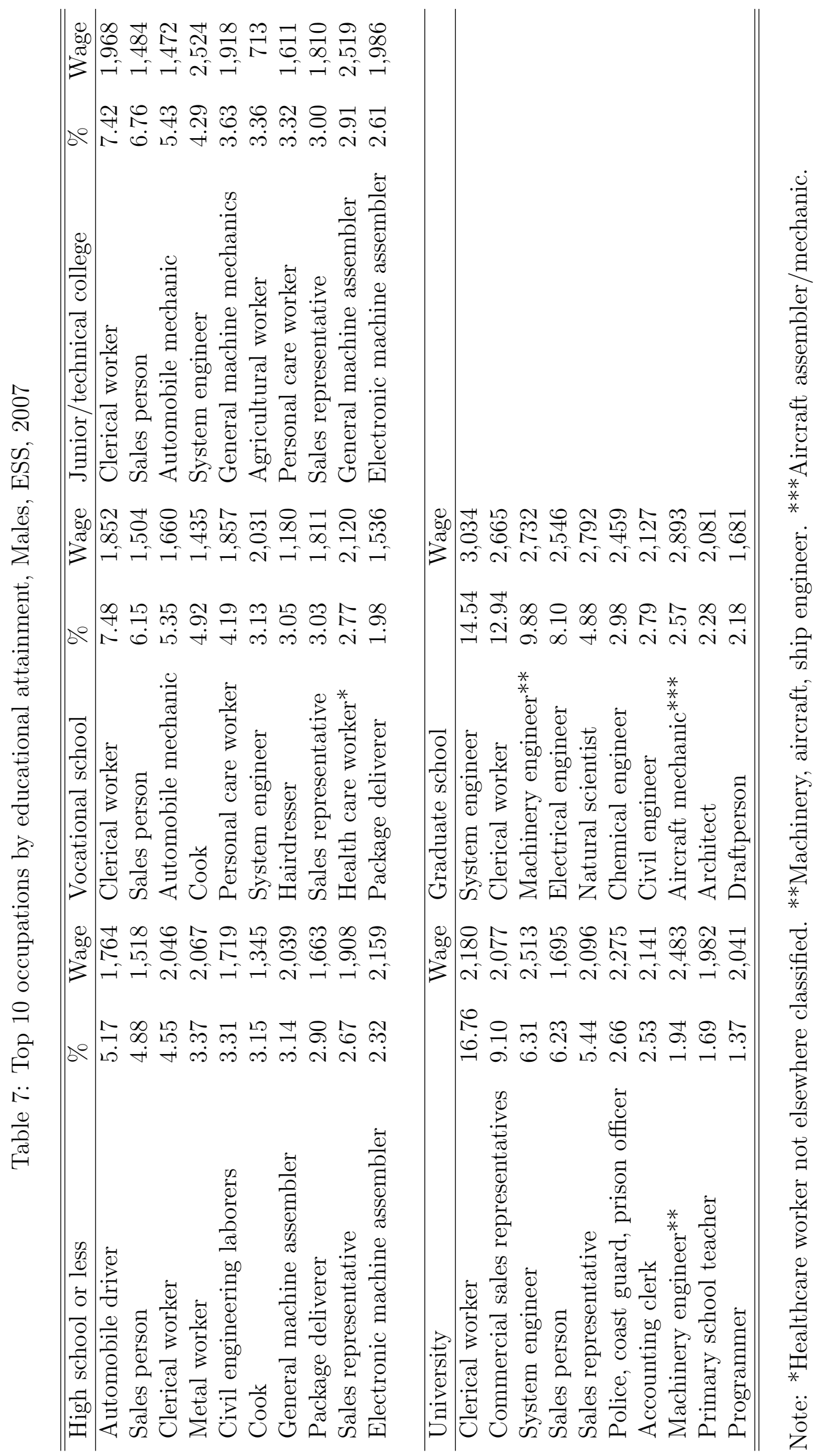




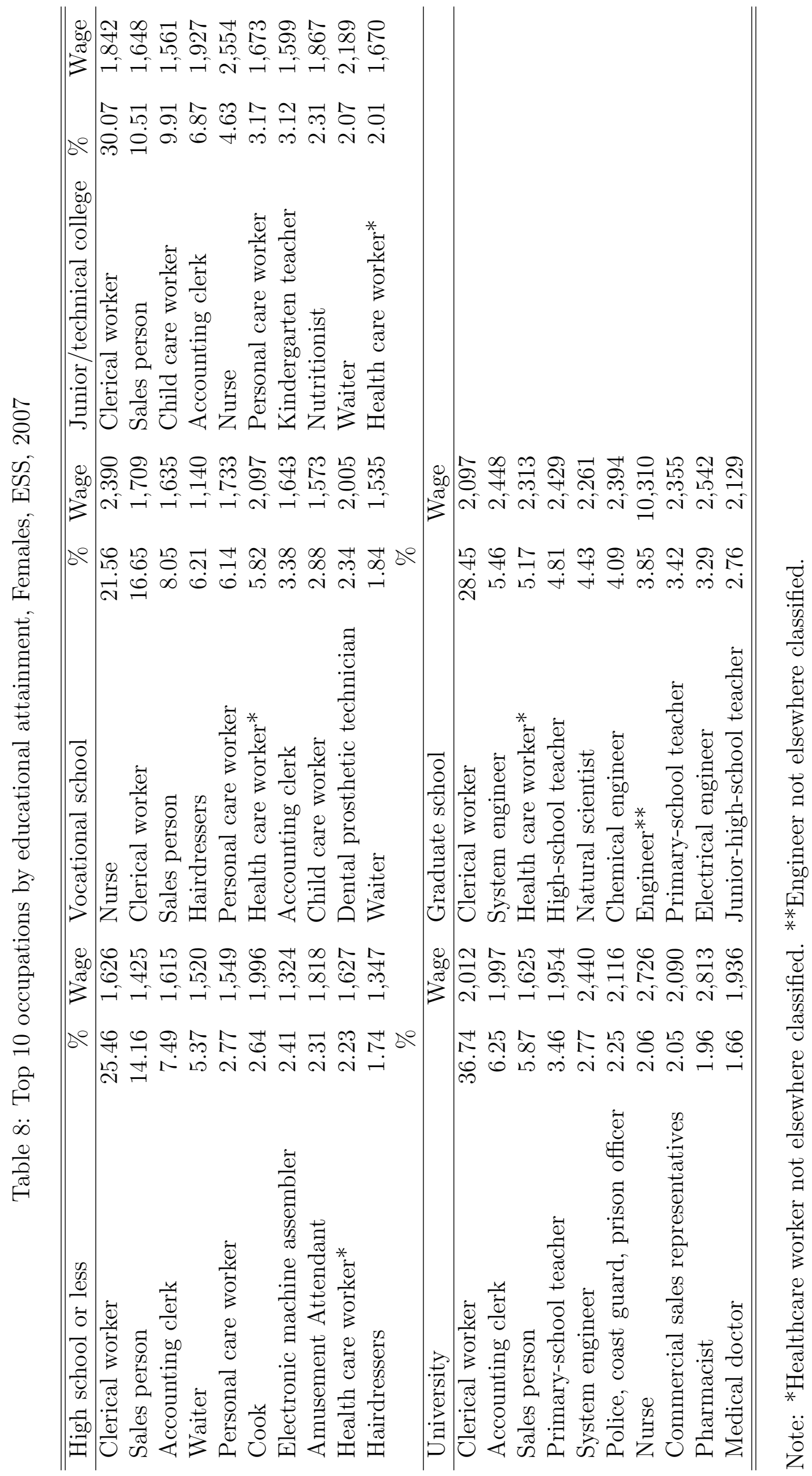

